\title{
Articles
}

\section{PRESIDENTIAL SIGNING STATEMENTS AND EXECUTIVE POWER}

\author{
Curtis A. Bradley* \\ Eric A. Posner**
}

\begin{abstract}
$A$ recent debate about the Bush administration's use of presidential signing statements has raised questions about their function, legality, and value. We argue that presidential signing statements are legal and that they provide a useful way for the president to disclose his views about the meaning and constitutionality of legislation. In addition, basic tenets of positive political theory suggest that signing statements do not undermine the separation of powers or the legislative process and that, under certain circumstances, they can provide relevant evidence of statutory meaning. Although President Bush has raised many more constitutional challenges within his signing statements than prior presidents have, at least on their face these challenges are similar to challenges made by other recent presidents, such as President Clinton. Whether Bush's views of executive power are significantly different from Clinton's, and if so, whether they are inferior, remain open questions, but these issues are independent of whether signing statements are lawful.
\end{abstract}

* Richard and Marcy Horvitz Professor, Duke Law School.

* Kirkland \& Ellis Professor, University of Chicago Law School. We thank David Barron, Kathy Bradley, Martin Flaherty, Jack Goldsmith, John Harrison, Dawn Johnsen, Judith Kelley, Neil Kinkopf, Marty Lederman, John McGinnis, Ralf Michaels, Jonathan Mitchell, Sai Prakash, Barak Richman, Nick Rosenkranz, Adam Samaha, Neil Siegel, Paul Stephan, Cass Sunstein, Adrian Vermeule, Ed Whelan, John Yoo, and participants at a faculty workshop at Duke Law School for helpful comments, and Josh MacLeod and Stacey Nathan for valuable research assistance. 


\section{INTRODUCTION}

Presidential signing statements are short documents that presidents often issue when they sign a bill. They first appeared about two centuries ago, and they have been used routinely since the New Deal. Presidents use signing statements to describe a bill in general terms; to explain its purpose; to praise the bill's sponsors or supporters; to criticize Congress for going too far or not far enough in addressing the problem the bill is supposed to solve; to advance particular interpretations of specific provisions of the bill; to explain how officials in the executive branch will implement the bill; to explain how the bill will interact with existing statutes; and to remind Congress of the president's constitutional powers. A brief controversy about the Reagan administration's use of signing statements to supplement legislative history flared up in the mid-1980s but had no lasting effect. ${ }^{1}$ Hundreds of signing statements have been issued since then but until recently no one paid much attention to them. All this changed about a year ago, and suddenly the signing statement, as an institution, has become a topic of heated political debate.

In December 2005, President Bush signed into law the Detainee Treatment Act, which among other things prohibits the "cruel, inhuman, or degrading treatment or punishment" of anyone in U.S. custody. In a signing statement, Bush stated that he would construe the prohibition "in a manner consistent with the constitutional authority of the President to supervise the unitary executive branch and as Commander in Chief and consistent with the constitutional limitations on the judicial power," suggesting to some people that he might not comply with the prohibition.2 In March 2006, President Bush issued a signing statement for the reauthorization of the Patriot Act, in which he asserted that he had the authority to ignore certain reporting requirements. 3 Both of these events caught the attention of the media. Also, in January 2006, during Justice Samuel Alito's con-

1. Commentators at that time debated the legitimacy of using signing statements to express views about a statute's meaning. Compare Marc N. Garber \& Kurt A. Wimmer, Presidential Signing Statements as Interpretations of Legislative Intent: An Executive Aggrandizement of Power, 24 HARV. J. ON LEGIS. 363 (1987) (criticizing this practice), with Frank B. Cross, The Constitutional Legitimacy and Significance of Presidential "Signing Statements," 40 ADMIN. L. REV. 209 (1988) (defending this practice)

2. See Statement on Signing the Department of Defense, Emergency Supplemental Appropriations to Address Hurricanes in the Gulf of Mexico, and Pandemic Influenza Act, 2006, 41 WEEKLY COMP. PRES. DOC. 1918 (Dec. 30, 2005).

3. See Statement on Signing the USA PATRIOT Improvement and Reauthorization Act of 2005, 42 WEEKLy COMP. PRES. DOC. 425 (Mar. 9, 2006). 
firmation hearings, it was revealed that, as a Justice Department lawyer in the Reagan administration, Alito had drafted a memo considering how to implement a proposal to use signing statements more frequently to address questions of statutory interpretation. 4 Alito's critics argued that the memo showed that, as a Supreme Court justice, he would be too friendly to the executive branch.

The next step was to link together what might have remained episodic controversies, and connect them to the widely credited claim that the Bush administration had taken extreme positions on executive authority in its legal defense of its war-onterror policies. Several members of the media made this connection early on, ${ }^{5}$ but the spark was applied to the fuel on April 30, 2006, when a Boston Globe article asserted that Bush had "quietly claimed the authority to disregard more than 750 laws enacted since he took office," far more than any other president. ${ }^{6}$ This article provoked further controversy, including increasingly strident condemnations of the signing statement in the media? In early June, the American Bar Association appointed a task force "to examine constitutional and legal issues raised by the practice of presidents of the United States of attaching legal interpretations to federal legislation they sign." ${ }^{8}$ On June 27 , the Senate held hearings on the signing statement, during which Republican Arlen Specter expressed concerns about Bush's signing statements, and Democrat Patrick Leahy called them a "grave threat to our constitutional system of checks and balances." Academics have also leapt into the fray. ${ }^{10}$ And in July 2006, the

4. See Christopher Lec, Alito Once Made Case for Presidential Power, WASH. POST, Jan. 2, 2006, at A11; Memorandum from Samuel A. Alito, Jr., Deputy Assistant Attorney Gen., Office of Legal Counsel, to the Litigation Strategy Working Group (Feb. 5, 1986), available at hitp://www.archives.gov/news/samuel-alito/accession-060-89269/Acc060-89-269-box6-SG-LSWG-AlitotoLSWG-Feb1986.pdf.

5. See, e.g., Dahlia Lithwick, Sign Here: Presidential Signing Statements Are More Than Just Executive Branch Lunacy, SLATE, Jan. 30, 2006, http://www.slateuk.com/id/2134919/.

6. Charlie Savage, Bush Challenges Hundreds of Laws; President Cites Powers of His Office, Boston GLOBE, Apr. 30, 2006, at A1.

7. See, e.g., Editorial, Veto? Who Needs a Veto?, N.Y. TIMES, May 5, 2006, at A22; Elizabeth Drew, Power Grab, N.Y. REV. OF BOOKS, June 22, 2006, available at http://www.nybooks.com/articles/19092.

8. American Bar Association, Task Force on Presidential Signing Statements and the Separation of Powers Doctrine, http://www.abanet.org/op/signingstatements/ (last visited Dec. 2, 2006)

9. Jonathan Weisman, Bush's Challenges of Laws He Signed Is Criticized, WASH. PosT, June 28, 2006, at A9.

10. See, e.g., Phillip J. Cooper, George W. Bush, Edgar Allen Poe, and the Use and Abuse of Presidential Signing Statements, 35 PRESIDENTIAL STUD. Q. 515 (2005) [hereinafter Cooper, Use and Abuse]; Neil Kinkopf, Signing Statements and the President's Au- 
ABA task force issued a statement "oppos[ing] as contrary to the rule of law and our constitutional system of separation of powers, a President's issuance of signing statements to claim the authority or state the intention to disregard or decline to enforce all or part of a law he has signed, or to interpret such a law in a manner inconsistent with the clear intent of Congress."

The attack on the institution of signing statements is puzzling. Signing statements provide public information about a president's views of a statute and thus would seem to promote dialogue and accountability. Furthermore, courts pay little attention to signing statements; as a result, it is not clear how they can increase the president's authority vis-à-vis Congress. Some critics have pointed out that signing statements are sometimes instructions to subordinates, and so an aggressive signing statement could, in theory, direct officials in the executive branch, including prosecutors and agency personnel, not to enforce statutes on the basis of dubious constitutional theories. ${ }^{12}$ But it is already widely recognized that the president has considerable authority to allocate enforcement resources by giving priority to some statutes and not to others, and to order his agents to enforce statutes according to his interpretations of them. He certainly does not need a signing statement to do this; he could just write a memorandum to his subordinates. If his subordinates fail to enforce the law properly, they might be compelled to act by courts, or Congress might retaliate; whether the failure was the result of a signing statement or some other order or document is immaterial.

All of this suggests that the real concern is not with the institution of signing statements but with the Bush administration's underlying views of executive power. Unfortunately, the media and even much of the academic work on signing statements ignore this distinction, and instead imply that the signing statement is intrinsically suspect. The ABA task force report, for ex-

thority to Refuse to Enforce the Law (American Constitution Society for Law and Policy, June 2006), available at http://www.acslaw.org/files/Kinkopf-Signing\%20Statements $\% 20$ and \%20President's\%20Authority.pdf; Richard A. Epstein, The Problem with Presidential Signing Statements, CHICAGO TRIBUNE, July 16, 2006, at 5.

11. AMERICAN BAR ASSOCIATION, TASK FORCE ON PRESIDENTIAL Signing STATEMENTS AND THE SEPARATION OF POWERS DOCTRINE, REPORT WITH RECOMMENDATIONS 5 (2006), available at http://www.abanet.org/op/signingstatements /aba_final_signIng_statements_recommendation-report_7-24-06.pdf [hereinafter ABA TASK FORCE]. The ABA's House of Delegates approved the task force's proposed resolutions, after amending them to make clear that what was opposed was the "misuse" of signing statements. The amended version is available at http:/www.coherentbabble. com/signingstatements/ABAresolamended.pdf.

12. See, e.g., Cooper, Use and Abuse, supra note 10; Epstein, supra note 10. 
ample, offers itself as a critique of the signing statement but is really an argument that the president has an obligation to enforce all statutes that are enacted-an entirely different argument which, incidentally, is much more complex than the task force's two-page analysis suggests. ${ }^{13}$ A possible reason for this state of affairs is that the Bush administration's constitutional claims are extremely hard to evaluate, as a matter of political and constitutional theory, so it is tempting to use the signing statement as a kind of proxy for the Bush administration's underlying constitutional claims. The number of challenges in the signing statements is taken as a quantitative index of the Bush administration's excesses, with the extreme nature of a few of the signing statements used to bolster this claim. In a now forgotten episode of the Clinton administration, Republican critics similarly complained that Clinton issued too many executive orders and directives to agencies, and used them to circumvent Congress's powers. ${ }^{14}$ The problem with this argument is the same as the problem with the argument against signing statements: the relevant question is not how many documents are issued, but the content of the documents, which is much harder to criticize and evaluate than the number.

In this article, we try to clear up some of the controversy over signing statements in general and the Bush administration's use of them in particular. In doing so, we make two principal contributions to the debate. First, we present a more nuanced empirical assessment of the Bush administration's use of signing statements, focusing in particular on a quantitative and qualitative comparison of the signing statement practices of President Bush and President Clinton. Second, we use positive political theory-the most sophisticated work on legislative institutions

13. See ABA TASK FORCE, supra note 11, at 18-19. We criticize the arguments below. For now, we will just point out that the task force makes the broad argument that the President can never refuse to enforce statutes that he believes are unconstitutional, without attempting to reconcile this position with the substantial legal and historical materiais that suggest the contrary, including materials surveyed in an Office of Legal Counsel memorandum by Walter Dellinger that the task force cites and quotes from. See id. at 13. At one point in its report, however, the task force appears to recognize that sometimes it will be appropriate for a president to decline to enforce a statutory provision he believes to be unconstitutional. See id. at 23 .

14. See Kenneth R. Mayer, With the Stroke of a Pen: Executive Orders AND PREsidential PoWer 219 (2001); Elena Kagan, Presidential Administration, 114 HARV. L. REV. 2245, 2294-95 (2001). For some Clinton-era media reports, see Jonathan Weisman, Wielding the Power of the President's Pen, Baltimore SUN, Dec. 22, 1999, at 3A; Editorial, The Intruders, WALL ST. J., Jan. 6, 2000, at A22 ("This final year is going to bring a paroxysm of regulatory intrusion-through agency actions or Mr. Clinton's continued abuse of exccutive orders.") 
and statutory interpretation - to assess the institutional implications of signing statements.

Part II briefly describes the history of signing statements and considers in some detail the Bush administration's practice. Although President Bush has not issued an unusual number of signing statements, he has challenged an unusually high number of statutory provisions within his statements. Critics contend that this behavior shows that the Bush administration has significantly broader views of executive power than prior presidents. While this contention might be true, the text of the signing statements do not by themselves provide compelling support for it. For the most part, the claims made in President Bush's signing statements including claims relating to the "unitary executive"-are similar to the claims made by other recent presidents, such as President Clinton. In addition, there are other plausible explanations for the Bush administration's high number of challenges.

In Part III, we reject the legal criticisms of the signing statement that have been advanced by a few scholars, politicians, and journalists. This is mainly a stage-setting exercise because it turns out that the most plausible critiques of the signing statement are not formalistic legal arguments but are ones based on more general institutional concerns. Part IV addresses these institutional arguments, which can be found mainly in the positive political theory literature. We argue that these institutional arguments, on inspection, turn out to be weak and that the institution of the signing statement does not present a serious threat to either the separation of powers or the legislative process.

\section{THE SIGNING STATEMENT: BACKGROUND}

\section{A. HISTORY PRIOR TO BUSH II}

Presidents have issued signing statements since early in U.S. history, starting with James Monroe. ${ }^{15}$ Despite early historical precedent, the signing statement did not come into widespread use until the twentieth century. According to statistics compiled by the political scientist Christopher Kelley, Hoover issued 12 signing statements; FDR issued 51; Truman issued 118; Eisenhower issued 145; Kennedy issued 80; and Johnson issued 302.

15. See Christopher N. May, Presidential Defiance of "Unconstitutional" Laws: Reviving the Royal Prerogative, 21 HASTINGS CONST. L.Q. 865, 929 n.294 (1994); Christopher S. Kelley, The Unitary Executive and the Presidential Signing Statement 57 (2003) (unpublished Ph.D. dissertation, Miami University). 
The remaining presidents up until Bush II issued between 100 and 400 signing statements during their administrations, averaging about 35 to 60 per year. ${ }^{16}$

Presidents use signing statements for diverse purposes. Many signing statements express general policy views without asserting that the bill must be interpreted or limited in some fashion. President Truman, for example, declared that various provisions of the Displaced Persons Act (which granted visas to certain people displaced by hostilities during World War II) "form a pattern of discrimination and intolerance wholly inconsistent with the American sense of justice." ${ }^{17}$ Presidents frequently sign legislation while declaring that the legislation does not go far enough toward solving the problem at hand, and requesting Congress to consider additional legislative proposals in the future. In his signing statement for the Antiterrorism and Effective Death Penalty Act of 1996, President Clinton complained that Congress did not adopt many of his proposals, including provisions to expand the wiretapping authority of law enforcement agencies and to ban "cop-killer bullets," and asked Congress to reconsider its decisions in future legislation. ${ }^{18}$ Many other signing statements have thanked constituents, praised or condemned members of Congress, and praised members of the executive branch as well as the administration itself. ${ }^{19}$ These types of signing statements have political value but no legal effect, and so we will not address them further.

The kinds of signing statements that have produced controversy in recent years also have substantial precedents in earlier administrations. We can divide these signing statements into two types. First, constitutional signing statements declare that the president will interpret a statute narrowly in order to avoid constitutional difficulties or not enforce a provision that the president believes is unconstitutional. President Truman interpreted a bill that provided for loans to Spain as an "authorization" rather than as a "directive" apparently because he believed that the latter

16. Kelley, supra note 15 , at 192 . We rely heavily on Kelley's valuable history in this part. Other useful sources on the history of signing statements include PHILLIP $\mathbf{J}$. COOPER, By ORdER OF THE PRESIDENT: THE USE AND ABUSE OF EXECUTIVE DIRECT ACTION (2002); May, supra note 15, at 928-69.

17. Statement by the President Upon Signing the Displaced Persons Act, 1 PuB. PAPERS 382, 383 (June 25, 1948).

18. Statement on Signing the Antiterrorism and Effective Death Penalty Act of 1996, 1 PUB. PAPERs 630 (Apr. 24, 1996).

19. COOPER, supra note 16 , at 213-15 
would violate his constitutional power over foreign affairs. ${ }^{20}$ Presidents Ford and Carter frequently used signing statements to deny the constitutionality of legislative vetoes. ${ }^{27}$ President Reagan stated that a statutory provision that purported not to recognize the PLO would be interpreted as nonbinding because otherwise it would conflict with the president's recognition power. ${ }^{22}$ President Clinton stated that the Department of Justice would not enforce a provision of the Telecommunications Act of 1996 that prohibited the transmission of certain abortion-related speech over the Internet because the provision violated the First Amendment. ${ }^{23}$

Second, interpretive (or legislative history) signing statements argue that ambiguous provisions of a statute have a particular meaning, based on what the president understands (or claims) the purpose of the statute to have been. President Truman interpreted a labor statute that provided an ambiguous good-faith defense to employers so that the employer would have the burden of proof and could not avoid liability merely by showing that it did not intend to violate a rule. ${ }^{24}$ President Reagan interpreted a supplemental appropriations bill so that its restrictions on the promulgation of regulations would apply only to the type of regulations specifically identified in the bill and not to the regulatory program to which they were related. ${ }^{25}$ President George H.W. Bush's signing statement for the Civil Rights Act of 1991 advanced a narrow definition of disparate impact by endorsing the statement of a Republican senator in the legislative history. ${ }^{26}$ President Clinton provided an interpretation of an ambiguous term in the Federal Workforce Restructuring Act of 1994, saying only that his interpretation was "[c]onsistent with the clear intent of the Act." ${ }^{27}$ In these cases, the president provides his understanding of what the bill means, without trying to appeal to his constitutional powers.

20. Memorandum from Walter Dellinger, Assistant Attorney General, to Bernard M. Nussbaum, Counsel to the President app. at para. 9 (Nov. 3, 1993), available at http://www.usdoj.gov/olc/signing.htm.

21. Kelley, supra note 15 , at 76.

22. Id. at 45 (citing Statement on Signing the International Security and Development Cooperation Act of 1985, 2 PuB. PAPERS 983 (Aug. 8, 1985)).

23. Kelley, supra note 15 , at 156.

24. Id. at 62 (citing Statement on Signing Hobbs Bill, 1 PUB. PaPERs 336 (July 3 , 1946)).

25. Statement on Signing the Urgent Supplemental Appropriations Act, 1986, 2 PUB. PAPERS 906 (July 2, 1986).

26. Kelley, supra note 15, at 134-35.

27. Statement on Signing the Federal Workforce Manufacturing Act of 1994, 1 PLib. PAPERS 561 (March 30, 1994). 
Christopher Kelley argues that the history of the use of the signing statement reflects the rise of the theory of the "unitary executive," which he traces to the Reagan administration. ${ }^{28}$ We would put the argument differently. The increase in the frequency of the use of the signing statement is related to the rise of the national government beginning with the New Deal and the concomitant transfer of power from Congress to the president. As the federal government became larger and claimed for itself greater power over areas of life traditionally left to the states, it became necessary for Congress to pass more, or more farreaching or comprehensive, statutes. With more statutes, there would be more opportunities for conflict between Congress's and the president's constitutional powers, and more sources of legislative ambiguity. Relatedly, this period also saw the creation of independent agencies with an uncertain relationship to presidential authority. Presidents have naturally sought to defend their constitutional prerogatives and to advance interpretations of ambiguous statutes that might otherwise be applied inconsistently with these prerogatives. The signing statement became an instrument with which they have discharged these functions.

At the same time, as the national government grew, much of the day-to-day regulatory power moved from Congress to the president. Congress created enormous agencies, placed them in the executive branch, and ordered the agencies to issue regulations. Congress transferred this authority to the executive because it lacked the institutional capacity to make the kind of dayto-day regulation that it believed necessary in a modern, national economy, but it also tried to retain as much oversight control as it could. These efforts led to repeated clashes with presidents, who were willing to administer the regulatory edifice but believed that congressional micromanaging violated their constitutional powers. Signing statements became one of the ways that presidents have asserted their constitutional understandings. Thus, the increasingly frequent use of signing statements since FDR can be attributed to the gradual transfer of authority from Congress to the president as well as the growth of the national government itself. Indeed, many other indicia of executive power also increased during this period. For example, presidents used executive orders very rarely in the nineteenth century, but

28. Kelley, supra note 15 , at 184 . For discussion of this theory, see infra note 74 and accompanying text. 
frequently during the twentieth, with their greatest use occurring during the FDR and Truman administrations. ${ }^{29}$

The Reagan administration continued the practice of earlier administrations but in a somewhat more aggressive fashion. Reagan's attorney general, Edwin Meese, argued more vigorously and explicitly than any of his predecessors that the president's views on the Constitution, whether put in signing statements or elsewhere, should be given significant weight. ${ }^{30}$ Meese also argued that signing statements were a legitimate form of legislative history, on which courts should rely when interpreting statutes, regardless of whether the signing statement reflects the president's constitutional or policy views about the statute in question. ${ }^{31}$ We conjecture that the rise of this more aggressive use of the signing statement resulted from efforts to reclaim executive power in the wake of the Watergate scandal and the congressional reaction of the 1970 s, which involved the enactment of numerous laws intended to constrain the executiveincluding the War Powers Resolution, the Foreign Intelligence Surveillance Act, and the Anti-Impoundment Act. ${ }^{32}$

\section{B. BUSH II}

Like the signing statements of other recent presidents, President Bush's signing statements fall into three overlapping categories: statements made for public relations or political purposes; statements that express constitutional objections to or concerns about statutory provisions and thereby either suggest that they are not binding on the president or that they will be interpreted in a manner that avoids the objection or concern; and statements that express a view about the meaning of an ambiguous statutory provision.

Bush has often used signing statements at least partially for political or public relations purposes. For example, of the twenty-four signing statements that Bush issued in 2001, half of them were purely for political or public relations purposes, although it appears that there are fewer pure political/public relations signing statements in subsequent years. In signing into law

29. See MAYER, supra note 14 , at 71 .

30. See COOPER, supra note 16, at 201-03; Edwin Meese III, The Law of the Constiiution, 61 TUL. L. REV. 979 (1987).

31. The academic debate of the time focused on the question whether a signing statement reflecting policy should be used as legislative history and neglected the constitutional signing statement, which is the focus of the debate today.

32. See Arthur M. SChlesinger, JR., The Imperial Presidency 423 (2004). 
a bill that repealed a regulation concerning ergonomics, Bush stated that the "measure repeals an unduly burdensome and overly broad regulation" and further criticized the regulation as something that "would have cost both large and small employers billions of dollars and presented employers with overwhelming compliance challenges." 33 This statement made no claim about the meaning of statutory provisions and did not raise any constitutional objections about the bill. Similarly, in signing a supplemental appropriations bill in 2001, Bush "commend[ed] the Congress for expeditiously providing critical resources needed to improve our support for our men and women in the military while maintaining a strict fiscal discipline." ${ }^{34}$ The use of signing statements to make these sorts of political or public relations statements is not controversial.

Many of Bush's signing statements refer to constitutional objections or concerns implicated by one or more statutory provisions (often in addition to making public relations statements). These constitutional objections typically relate to asserted encroachments on executive authority. For example, Bush's statements have objected to:

- Provisions directing the executive branch to submit proposals or recommendations to Congress on particular topics, on the ground that they interfere with the constitutional authority of the president to recommend "such measures as the President shall judge necessary or expedient."35

- Restrictions on the president's ability to appoint officers or vest appointment authority in entities other than the president, on the ground that they violate the Appointments Clause. ${ }^{36}$

- Provisions requiring the submission of information to Congress, on the ground that they may interfere with the president's authority to withhold information for various reasons, such as harm to national security. ${ }^{37}$

33. Statement on Signing Legislation To Repeal Federal Ergonomics Regulations, 1 PUb. PAPERS 269, 269 (Mar. 20, 2001).

34. Statement on Signing the Supplemental Appropriations Act, FY 2001, 2 PuB. PAPERS 908, 908 (July 24, 2001)

35. See, e.g., Statement on Signing Legislation to Provide for Improvement of Fedcral Education Research, Statistics, Evaluation, Information, and Dissemination, and for Other Purposes, 38 WeEkLY COMP. PRES. DoC. 1995, 1995 (Nov. 5, 2002).

36. See, e.g., Statement on Signing the Transportation, Treasury, Housing and Urban Development, the Judiciary, the District of Columbia, and Independent Agencies Appropriations Act, 2006, 41 WEEKLy COMP. PRES. DOC. 1800 (Nov. 30, 2005).

37. See, e.g., Statement on Signing the Intelligence Reform and Terrorism Preven- 
- Provisions directing the executive branch to take particular positions in international negotiations or before international bodies, or to report on international negotiations, on the ground that they interfere with the president's management of foreign affairs. ${ }^{38}$

- Limitations on the use of U.S. armed forces, on the ground that they interfere with the president's Commander in Chief authority. ${ }^{39}$

- Provisions that regulate how actions are to be taken within the executive branch, on the ground that they interfere with the president's authority to supervise the "unitary executive branch."

- Legislative veto and approval provisions on the ground that they are inconsistent with the Supreme Court's decision in INS v. Chadha. ${ }^{41}$

Many of Bush's signing statements refer to multiple constitutional concerns, with the highest number often being raised in connection with appropriations bills. In signing an appropriations bill in November 2001, for example, Bush raised constitutional concerns about requirements regarding the organization of the Department of Justice's efforts to combat terrorism; a requirement that the president submit a legislative proposal to Congress concerning compensation for victims of terrorism; and a prohibition on the use of appropriated funds for cooperation with, or assistance or other support to, the International Criminal Court. He also noted at the end of his signing statement that "several other provisions of the bill unconstitutionally constrain my authority regarding the conduct of diplomacy and my authority as Commander-in-Chief," and that he would "ap-

tion Act of 2004, 40 WEEKLY COMP. PRES. DOC. 2993 (Dec. 17, 2004).

38. See, e.g., Statement on Signing the Foreign Relations Authorization Act, Fiscal Year 2003, 38 WEEKLy COMP. PRES. DOC. 1658 (Sept. 30, 2002); Statement on Signing the Foreign Operations, Export Financing, and Related Programs Appropriations Act, 2006, 41 WEEKLY COMP. PRES. DOC. 1718 (Nov. 14, 2005)

39. See, e.g., Statement on Signing the Ronald W. Reagan National Defense Authorization Act for Fiscal Year 2005, 40 WEEKLY COMP. PRES. Doc. 2673 (Oct. 28, 2004).

40. See, e.g., Statement on Signing the Consolidated Appropriations Act, 2005, 40 WEEKLY COMP. PRES. DOC. 2924 (Dec. 8, 2004).

41. See, e.g., Statement on Signing the Department of the Interior and Related Agencies Appropriations Act, 2004, 39 WEEKLY COMP. PRES. DOC. 1576 (Nov. 10, 2003). For additional discussion of the types of constitutional concerns raised in President Bush's signing statements, see Time Change-Presidential Signing Statements: Hearing on Presidential Signing Statements Before the S. Comm. on the Judiciary (June 27, 2006) [hereinafter Time Change] (statement of Michelle E. Boardman, Deputy Assistant Attorney Gen., Office of Legal Counsel, Dept. of Justice), available at http://judiciary.senatc.gov/hearing.cfm?id=1969; Cooper, Use and Abuse, supra note 10, at 522 . 
ply these provisions consistent with my constitutional responsibilities." 42 In his signing statements for the Consolidated Appropriations Act of 2004 and the Consolidated Appropriations Act of 2005, Bush referred to constitutional concerns relating to dozens of provisions. ${ }^{43}$

Most of the time, when Bush has identified a constitutional concern, he has stated that he will construe the statutory provision in question in a manner to avoid the concern. For example, in signing the Animal Disease Risk Assessment, Prevention, and Control Act of 2001, Bush noted that a section of the Act required the Secretary of Agriculture to submit certain reports to committees and subcommittees of Congress, and he explained that this section "will be interpreted in a manner consistent with the constitutional authority of the President to recommend to the consideration of the Congress such measures as the President shall judge necessary and expedient." ${ }^{, 4}$ Similarly, in signing an appropriations act for the Department of the Interior, he noted that "[s]everal provisions in the bill purport to require congressional approval before executive branch execution of aspects of the bill," and that he would "interpret such provisions to require notification only, since any other interpretation would contradict the Supreme Court ruling in INS v. Chadha." ${ }^{45}$

For many of his constitutional objections, Bush has addressed the issue by interpreting statutory language that otherwise appears to be mandatory as being merely advisory. For example, in signing the Foreign Operations Appropriations Act in 2002 , he stated that a provision that called for the Department of State to provide briefings to congressional committees concerning certain discussions with foreign governments

shall be construed as advisory only, given the constitutional powers of the President to supervise the executive branch and to conduct the Nation's foreign affairs, which includes the authority to determine what information about international ne-

42. Statement on Signing the Departments of Commerce, Justice, and State, the Judiciary, and Related Agencies Appropriations Act, 2002, 2 PLB. PAPERS 1458, 1459 (Nov. 28, 2001).

43. Statement on Signing the Consolidated Appropriations Act, 2004, 40 WEEKLY COMP. PRES. DOC. 137 (Jan. 23, 2004), available at htlp://www.presidency.ucsb. edu/ws/print.php?pid=72537; Statement on Signing the Consolidated Appropriations Act, 2005, 40 WEEKLY COMP. PRES. DOC. 2924 (Dec. 8, 2004).

44. Statement on Signing the Animal Disease Risk Assessment, Prevention, and Control Act of 2001, 1 PUB. PAPERS 575, 575 (May 24, 2001)

45. Statement on Signing the Department of the Interior and Related Agencies Appropriations Act, 2002, 2 Pub. PAPERS 1346, 1346 (Nov. 5, 2001). 
gotiations may, in the public interest, be made available to the

Congress and when such disclosure should occur. ${ }^{46}$

Similarly, in signing the National Science Foundation Authorization Act of 2002, he noted that a section of the bill "purports to condition authorizations of certain appropriations on a subsequent determination by the Congress of the existence of successful progress by the executive branch toward specified goals," and that "[t]he executive branch shall construe the purported condition as advisory, since any other construction would be inconsistent with the principles enunciated by the U.S. Supreme Court in 1983 in INS v. Chadha."

In some signing statements, Bush has indicated that he would at least partially comply with statutory provisions that he thought were constitutionally problematic, particularly provisions relating to notice or reporting to Congress, "as a matter of comity." He did so, for example, in connection with the abovenoted objection to the reporting provision in the Foreign Operations Appropriations Act in 2002, stating "[t]he Secretary of State will, however, as a matter of comity between the executive and legislative branches, keep the Congress appropriately informed of the matters addressed by [this section]." ${ }^{48}$ Similarly, in signing the Military Construction Appropriations Act of 2004, Bush noted that some sections "provide for notice to the Congress of relocation of activities between military installations, initiation of a new installation abroad, or U.S. military exercises involving $\$ 100,000$ in construction costs," that "[ $t$ ]he Supreme Court of the United States has stated that the President's authority to classify and control access to information bearing on national security flows from the Constitution and does not depend upon a legislative grant of authority," and that "[a]lthough notice can be provided in most situations as a matter of comity, situations may arise, especially in wartime, in which the President must act promptly under his constitutional grants of executive power and authority as Commander in Chief while protecting sensitive national security information." ${ }^{49}$

46. Statement on Signing the Foreign Operations, Export Financing, and Related Programs Appropriations Act, 2002, 38 WEEKLY COMP. PRES. DOC. 49, 50 (Jan. 10, 2002).

47. Statement on Signing the National Science Foundation Authorization Act of 2002, 38 WEEKLY COMP. PRES. DOC. 2178, 2178 (Dec. 19, 2002).

48. Statement on Signing the Foreign Operations, Export Financing, and Related Programs Appropriations Act, 2002, 38 WEEKLY COMP. PRES. DoC. 49, 50 (Jan. 10, 2002).

49. Statement on Signing the Military Construction Appropriations Act, 2004, 39 
Bush has only rarely issued statements interpreting a statutory provision for non-constitutional reasons. He has done so to address accidental references or omissions in statutory language. ${ }^{50} \mathrm{He}$ has also occasionally done so to clarify statutory references. ${ }^{51}$ Most famously, in his signing statement for the Detainee Treatment Act in 2005, Bush asserted that the restrictions on habeas corpus in the Act applied to pending cases, ${ }^{52}$ a proposition subsequently rejected by the Supreme Court. ${ }^{53}$ In signing the Corporate Accountability, Responsibility and Transparency Act of 2002, also known as "Sarbanes-Oxley," Bush issued two signing statements, one formal and the other informal. In the informal statement, he said that he would construe a whistleblower protection provision narrowly. After subsequent pressure from Congress and interest groups, the executive branch changed its position and accepted a broader interpretation of the provision. ${ }^{54}$

\section{Bush II V. CLINTON}

It has been widely asserted that the Bush administration's practice with respect to signing statements has been unusual in nature and unprecedented in number. The press has frequently reported that Bush has issued a record number of signing state-

WEEKLY COMP. PRES. DOC. 1680.1680 (Nov. 22, 2003).

50. See Statement on Signing the Enhanced Border Security and Visa Entry Reform Act of 2002, 38 WEEKLY COMP. PRES. DOC. 822, 822 (May 14, 2002) ("Section $2(4)(G)$ of the Act defines as a Federal law enforcement agency the Coastal Security Service.' Because no such agency exists, and the principal agency with coastal security functions is the U.S. Coast Guard, the exccutive branch shall construe this provision as referring to the Coast Guard."); Statement on Signing the Vicksburg National Military Park Boundary Modification Act of 2002, 40 WEEKLY COMP. PRES. DOC. 1745, 1746 (Oct. 11, 2002) (noting that there was a missing word between "Secretary" and "add" and concluding that Congress intended the missing word to be "shall").

51. See, e.g., Statement on Signing the Consolidated Appropriations Act, 2005, 40 WEEKLY COMP. PRES. DOC. 2924, 2926 (Dec. 8, 2004) ("As is consistent with the principle of statutory construction of giving effect to each of two statutes addressing the same subject whenever they can co-exist, the executive branch shall construe the provision in the Energy and Water Appropriations Act under the heading 'National Nuclear Security Administration, Weapons Activities' concerning transfer of funds from the Department of Defense to constitute an 'express authorization of Congress' to which section 8063 of the Department of Defense Appropriations Act, 2005 (Public Law 108-287) refers.").

52. See Statement on Signing the Department of Defense, Emergency Supplemental Appropriations to Address Hurricanes in the Gulf of Mexico, and Pandemic Influenza Act, 2006, 41 WEEKLY COMP. PRES. DOC. 1918 (Dec. 30, 2005).

53. See Hamdan v. Rumsfeld, 126 S. Ct. 2749, 2764-69 (2006)

54. See Christopher S. Kelley, Rethinking Presidential Power-The Unitary Executive and the George W. Bush Presidency 34-39 (A pr. 2005) (paper prepared for the 63d Annual Meeting of the Midwest Political Science Association), available at hitp:// www.pegc.us/archive/Unitary\%20Executive/kelly_unit_exec_and_bush.pdf. 
ments. ${ }^{55}$ As we noted earlier, it was also reported in April 2006 that President Bush had already asserted the authority to disregard "more than 750 laws since he took office," something "unprecedented in US history." ${ }^{\text {"S6 }}$ Senator Specter has noted that, "[t]here is a sense that the president has taken the signing statements far beyond the customary purview." ${ }^{57}$ The political scientist Phillip Cooper contends that President Bush has "expanded the scope and character of the signing statement." 58

In this section, we try to evaluate this claim, focusing on a comparison between Bush's practice and Clinton's. Clinton's signing statements provide a natural basis for comparison because Clinton was Bush's immediate predecessor and belonged to the other party. Of course, there is no reason to think that Bush's practice should be identical to Clinton's. They could have good-faith disagreement about the scope of executive power. In addition, the circumstances of the two administrations are dramatically different - with Clinton's taking place during a time of peace and optimism, and Bush's, except for part of the first year, occurring after the 9/11 attacks. These attacks allowed Bush to invoke the tradition of deference to the executive during military emergencies, and perhaps made him and his subordinates more aggressive about asserting presidential powers vis-à-vis Congress in his signing statements. We will return to these issues shortly.

We begin with some numbers. Although Christopher Kelley and others have provided useful statistics regarding signing statements, there is uncertainty about how to categorize the statements (and Kelley has himself revised his statistics because of this), ${ }^{59}$ so we started from scratch and compiled our own statistics. We coded all of the statements issued from Carter through Bush II, using the three categories of "rhetorical," "constitutional," and "interpretive." For the constitutional category,

55. See, e.g., Susan Page, How Bush Has Asserted Powers of the Executive, USA TODAY, June 6, 2006, at 2A; The Week, The Heat Is On: July 23-29, N.Y. TimES, July 30, $2006, \S 4$, at 2; Editorial, Read the Fine Print, N.Y. TIMES, July 25, 2006, at A18.

56. Savage, supra note 6, at A1; see also Boston Globe, Number of New Statutes Challenged, http://www.boston.com/news/nation/washington/articles/2006/04/30/statutes_ challenged/ (providing chart, which purports to show that the first President Bush challenged 232 laws; Clinton challenged 140 laws; and Bush II challenged "at least 750" laws).

57. Weisman, supra note 9, at A9.

58. Cooper, Use and Abuse, supra note 10, at 516; see also Lithwick, supra note 5 ("[T] he difference between President Bush's use of the statements and that of his predecessors is a matter of frequency and kind.").

59. See And Then Spoke the ABA, http:/www.users.muohio.edu/kelleycs/mediablog. html (July 24, 2006, 18:00). 
we also counted all sections within a bill concerning which constitutional concerns were being raised. Finally, we computed yearly averages for the various figures. Because the coding requires judgment, it is not surprising that our statistics differ in some respects from those compiled by others. But the major patterns are the same, and so we are confident that our picture, in at least rough outlines, is correct. ${ }^{60}$ Table 1 provides the data.

Table 1

\begin{tabular}{|c|c|c|c|c|c|}
\hline & Carter & Reagan & $\begin{array}{c}\text { Bush } \\
\text { I }\end{array}$ & Clinton & $\begin{array}{c}\text { Bush } \\
\text { II }\end{array}$ \\
\hline $\begin{array}{l}\text { Signing Statements, } \\
\text { Aggregate }\end{array}$ & 225 & 250 & 228 & 381 & 132 \\
\hline - rhetorical & 193 & 164 & 121 & 311 & 25 \\
\hline - constitutional & 16 & 61 & 98 & 65 & 104 \\
\hline - legislative history & 16 & 29 & 21 & 12 & 27 \\
\hline $\begin{array}{l}\text { SS's Containing Challenges, } \\
\text { Aggregate }\end{array}$ & 32 & 86 & 107 & 70 & 106 \\
\hline $\begin{array}{l}\text { Sections Challenged, } \\
\text { Aggregate }\end{array}$ & 39 & 129 & 169 & 144 & 844 \\
\hline $\begin{array}{l}\text { - SS's with challenges to an } \\
\text { undefined number of sec- } \\
\text { tions }\end{array}$ & 2 & 4 & 29 & 12 & 14 \\
\hline Average SS's Per Year & 56 & 31 & 57 & 48 & 25 \\
\hline $\begin{array}{l}\text { - average rhetorical per } \\
\text { year }\end{array}$ & 48 & 21 & 30 & 39 & 5 \\
\hline $\begin{array}{l}\text { - average constitutional per } \\
\text { year }\end{array}$ & 4 & 8 & 24 & 8 & 20 \\
\hline $\begin{array}{l}\text { - average legislative history } \\
\text { per year }\end{array}$ & 4 & 4 & 5 & 2 & 5 \\
\hline $\begin{array}{l}\text { Average Yearly SS's with } \\
\text { Challenges }\end{array}$ & 8 & 11 & 27 & 9 & 20 \\
\hline $\begin{array}{l}\text { Average Yearly Sections } \\
\text { Challenged }\end{array}$ & 10 & 16 & 42 & 18 & 162 \\
\hline $\begin{array}{l}\text { - average yearly SS's with } \\
\text { challenges to an unde- } \\
\text { fined number of sections }\end{array}$ & 1 & 1 & 9 & 1 & 2 \\
\hline
\end{tabular}

*Note: Bush's aggregate number is through June 2006; his averages exclude 2006 because it was an incomplete year. Rhetorical signing

60. We did not do the coding ourselves but used a law student rescarch assistant who was directed to apply the categorics specilied in the table. 
statements are purely rhetorical; no legislative or constitutional claims are made. Unlike others before us, we classify signing statements as "constitutional" or "legislative history" only if they contain legal claims. A signing statement with both constitutional and legislative claims is counted once in row 2 and once in row 3 , but only once in row 1 . We have separated out signing statements that challenge an undefined number of statutory provisions, and do not attempt to estimate how many are in fact challenged. Numbers have been rounded.

This table does show that Bush's practice has been quantitatively unusual, but not in the simple way reported in the press. It is important to distinguish the number of signing statements that a president issues and the number of challenges to statutory provisions that he makes in his signing statements. In the first category, Bush does not differ much from his predecessors. In five and one half years (ending June 30,2006) he issued 132 signing statements, fewer than Carter issued in four years. Bush issued fewer signing statements on an annual basis (25) than any of his predecessors in our table, and indeed back to President Kennedy. ${ }^{61}$

Moreover, even if one considers only signing statements that challenge statutory provisions, Bush is on the high end but still not outside the historical norm. His 20 signing statements per year with constitutional challenges are substantially higher than Clinton's (8) and Reagan's (8) but lower than G.H.W. Bush's (25). When one includes challenges based on legislative history, Bush's number remains at 20 while Clinton's rises to 9 and G.H.W. Bush's rises to 27.

However, Bush has clearly departed from the norm by frequently issuing challenges to numerous statutory provisions within a single signing statement. As of June 2006, Bush had challenged more than 800 statutory provisions, which is much higher than any prior president. On average, Bush challenged 162 statutory provisions per year; by contrast Clinton challenged 18 and G.H.W. Bush challenged 42. A typical Bush signing statement that is not purely rhetorical might challenge a halfdozen or more statutory provisions; other presidents would typically challenge only one or two ${ }^{62}-$ though Clinton in some cases

61. See Kelley, supra note 15 , app. 3.1 at 192 (providing support of the approximate number of signing statements per year, on average: Ford -54 ; Nixon-30; Johnson-60; Kennedy - 27).

62. Compare Statement on Signing the Agriculture, Rural Development, Food and Drug Administration, and Related Agencies Appropriations Act, 2006, 41 WEEKLY COMP. PRES. DOC. 1701 (Nov. 10, 2005), with Statement on Signing the Department of the Interior and Related Agencies Appropriations Act, 1995, 2 PUB. PAPERS 1674 (Sept. 30, 1994). 
challenged a large number of provisions, ${ }^{63}$ and both presidents sometimes challenged an undefined number of provisions. ${ }^{64}$

Before we discuss why Bush's practice might depart from that of his predecessors, we should provide some context. Eight hundred "provisions" sounds scary, but a statutory "provision" challenged in a signing statement is typically just a few lines, sometimes a bit more. Thus, in an average year during which Bush challenges 162 provisions, one might usefully think of this as the equivalent of about four to five pages of statutes. During this average year, Bush will have signed about 200 laws with an aggregate page total of around 35,000. Thus, although Bush has challenged many more statutory provisions than his predecessors, the fraction of statutory material that he has challenged remains trivial, less than $1 / 1000$ th. To be sure, some onesentence statutory provisions are of great significance, and many others are of little importance; but this is just to say that numbers do not tell one much about whether the Bush administration's behavior has been important or not.

What accounts for the substantial increase in the frequency of challenges within particular signing statements? It cannot be attributed to an increase in the number of statutes or statutory provisions, or an increase in the length of statutes, as far as we can tell. ${ }^{65}$ Nor does it seem likely that the 2001-2006 Congresses enacted more constitutionally problematic legislation than the 1993-2000 Congresses. Although legislation relating to the war on terror and war in Iraq might pose more potential conflicts with executive authority than peacetime legislation, many of the constitutional challenges are not related to foreign affairs, and Congress during much of the 2001-2006 period was of the same party as the president and thus if anything less likely to include provisions that the president believed to be objectionable. ${ }^{66}$

63. E.g., Statement on Signing the Foreign Relations Authorization Act, Fiscal Years 1994 and 1995, 1 PUB. PAPERS 807 (Apr. 30, 1994).

64. See Statement on Signing the National Defense Authorization Act for Fiscal Year 1997, 2 PUB. PAPERS 1645 (Sept. 23, 1996); Statement on Signing the Energy and Water Development Appropriations Act, 2002, 2 PuB. PAPERS 1389 (Nov. 12, 2001).

65. Fewer statutes were enacted annually during the Bush administration than in prior administrations. The numbers are as follows: Carter-311; Reagan-308; G.H.W. Bush-310; Clinton-232; G.W. Bush-211. (Westlaw Pub. Law database) (excludes 2006). The average length of statutes (in pages) for Clinton and G.W. Bush were roughly the same, indicating that the length or complexity of statutes is not likely the source of the difference in the frequency of challenges.

66. One can imagine explanations for why constitutional signing statements would go up with a same-party Congress-lor example, a same-party Congress might enact bolder legislation, or might include problematic provisions for symbolic value while tac- 
One possibility, of course, is that the Bush administration has challenged more provisions because it has significantly broader views of executive power than the Clinton administration. We acknowledge this possibility, but we would note that the text of the signing statements do not by themselves provide compelling support for it. Rather, when one compares the wording of the Bush II and Clinton signing statements, there are striking similarities.

As we noted above, Bush has objected to provisions directing the executive branch to submit proposals or recommendations to Congress on particular topics, on the ground that they interfere with the constitutional authority of the president to "recommend ... such Measures as he shall judge necessary and expedient." Clinton used the same language in a signing statement for the Balanced Budget Act of 1997:

Section 4422 of the bill purports to require the Secretary of Health and Human Services to develop a legislative proposal for establishing a case-mix adjusted prospective payment system for payment of long-term care hospitals under the Medicare program. I will construe this provision in light of my constitutional duty and authority to recommend to the Congress such legislative measures as I judge necessary and expedient, and to supervise and guide my subordinates, including the review of their proposed communications to the Congress. ${ }^{67}$

Bush has objected to provisions that restrict the president's ability to appoint officers or vest appointment authority in entities other than the president, on the ground that they violate the Appointments Clause. Clinton raised an Appointments Clause objection in the Coast Guard Authorization Act of 1997:

One section of the Act, Section 1002, raises a constitutional concern. This section establishes a committee empowered to select the entities to which certain historic lighthouses will be conveyed. Because the committee members will hold a Federal office and because this section vests them with significant authority, they must be appointed as officers pursuant to the Appointments Clause of the Constitution. The Act, however, provides that the Secretary of Transportation "shall" appoint four of the committee's five members from among persons recommended or designated by certain Maine officials or or-

itly accepting the president's authority to ignore them-but these explanations are very speculative.

67. Statement on Signing the Balanced Budget Act of 1997, 2 PUB. PAPERS 1053, 1054 (Aug. 5, 1997) (emphasis added). 
ganizations. The Appointments Clause does not permit such restrictions to be imposed upon the executive branch's powers of appointment. Therefore, I will not interpret section 1002(d)(3)(A) of the Act as binding, and I direct the Secretary of Transportation to regard the designations and recommendations arising from it as advisory only. ${ }^{68}$

Bush has objected to provisions requiring the submission of information to Congress, on the ground that they may interfere with the president's authority to withhold information for various reasons, such as harm to national security. In signing a Joint Resolution concerning U.S. policy towards Haiti, President Clinton stated:

In signing this joint resolution, it is important to clarify the interpretation of a provision related to the President's authority and responsibility as Commander in Chief.

Section 2 of the resolution calls, inter alia, for a detailed description of "the general rules of engagement under which operations of the United States Armed Forces are conducted in and around Haiti." I interpret this language as seeking only information about the rules of engagement that I may supply consistent with my constitutional responsibilities, and not information of a sensitive operational nature. ${ }^{69}$

Bush has objected to provisions directing the executive branch to take particular positions in international negotiations or before international bodies, or to report on international negotiations, on the ground that they interfere with the president's

68. Statement on Signing the Coast Guard Authorization Act of 1996, 2 PUB. PAPERS 1869, 1870 (Oct. 19, 1996); see also Statement on Signing the National Defensc Authorization Act for Fiscal Year 1997, 2 PUB. PAPERS 1645 (Sept. 23, 1996). We are not claiming that the Bush and Clinton administrations had precisely the same views of the scope of the Appointments Clause. The Clinton administration apparently viewed the Clause as limited to persons employed to hold a federal office, see The Constitutional Separation of Powers Between the President and Congress, 20 Op. Off. Legal Counsel 124,140 (1996), whereas the Bush administration apparently has a broader view that extends the Clause to persons exercising federal power. Our claim is simply that Clinton, like Bush, was vigorous in asserting Appointments Clause objections. See also Memorandum from Christopher Schroeder, Assistant Attorney Gen., Office of Legal Counsel, to the Counsel to the President (July 1, 1996), available at http://www.usdoj.gov/ olc/barsh2.htm (concluding that congressional restriction on qualifications for U.S. Trade Representative violated the Appointments Clause and could be disregarded by the President).

69. Statement on Signing Legislation Regarding United States Policy Towards Haiti, 2 PUB. PAPERS 1897, 1897 (Oct. 25, 1994), available at http://www.presidency. ucsb.edu/ws/index.php?pid=49382 
management of foreign affairs. In his signing statement for the National Defense Authorization Act of 1997, Clinton said:

Provisions purporting to require the President to enter into or report on specified negotiations with foreign governments, as well as a provision that limits the information that could be revealed in negotiations, intrude on the President's constitutional authority to conduct the Nation's diplomacy and the President's role as Commander in Chief. I will interpret these provisions as precatory. ${ }^{70}$

Bush has objected to provisions that limit the use of U.S. armed forces, on the ground that they interfere with the president's Commander in Chief authority. Clinton raised the same objections in his signing statement for a 1993 appropriations bill:

However, I do have serious reservations about a provision in section 8151 of this Act. I construe section 8151(b)(2)(ii) as not restricting my constitutional responsibility and authority as Commander in Chief, including my ability to place U.S. combat forces under the temporary tactical control of a foreign commander where to do otherwise would jeopardize the safety of U.S. combat forces in support of UNOSOM II. Such U.S. combat forces shall, however, remain under the operational command and control of U.S. commanders at all times. $^{71}$

Bush has objected to provisions that regulate how actions are to be taken within the executive branch, on the ground that they interfere with the president's authority to supervise the "unitary executive branch." By contrast with the Bush administration, Clinton never invoked the term "unitary executive" in his signing statements. However, he did make the identical complaints, without using this term. For example, his signing statement for the Balanced Budget Act of 1997 said:

Section 4422 of the bill purports to require the Secretary of Health and Human Services to develop a legislative proposal for establishing a case-mix adjusted prospective payment system for payment of long-term care hospitals under the Medicare program. I will construe this provision in light of my constitutional duty and authority to recommend to the Congress

70. Statement on Signing the National Defense Authorization Act for Fiscal Year 1997, 2 Pub. PAPERS 1645, 1646 (Sept. 23, 1996); see also Statement on Signing the Cuban Liberty and Democratic Solidarity (LIBERTAD) Act of 1996, 1 PUB. PAPERS 433 (Mar. 12, 1996).

71. Statement on Signing the Department of Defense Appropriations Act, 1994, 2 PUB. PAPERS 1958, 1958 (Nov. 11, 1993) 
such legislative measures as I judge necessary and expedient, and to supervise and guide my subordinates, including the review of their proposed communications to the Congress. ${ }^{72}$

Similarly, in signing the Treasury and General Government Act, President Clinton stated:

Section 640 of the bill prohibits the use of appropriations to pay the salary of any officer or employee of the Federal Government who interferes with certain communications or contacts between other Federal employees and Members of Congress or congressional committees. I understand this provision is intended to protect "whistleblower" employees who wish to inform the Congress of evidence of violations of law or other wrongdoing in the Government. Any broader interpretation of the provision that would apply to "nonwhistleblowers" would raise substantial constitutional concerns in depriving the President and his department and agency heads of their ability to supervise and control the operations and communications of the executive branch. I do not interpret this provision to detract from my constitutional authority in this way.

The central tenets of the unitary executive theory are "the president's power to remove subordinate policy-making officials at will, the president's power to direct the manner in which subordinate officials exercise discretionary executive power, and the president's power to veto or nullify such officials' exercises of discretionary executive power." then it appears to us that Clinton's signing statements reflect this theory.

Bush also has frequently objected to legislative veto and approval provisions on the ground that they are inconsistent with the Supreme Court's decision in INS v. Chadha ${ }^{76}$ Clinton did the same in a number of signing statements. ${ }^{.7}$

Finally, we should mention that Clinton, like Bush on occasion, used signing statements to advance interpretations of the

72. Statement on Signing the Balanced Budget Act of 1997, 2 PUB. PAPERS 1053, 1054 (Aug. 5, 1997) (emphasis added).

73. Statement on Signing the Treasury and General Government Appropriations Act, 1998, 2 PUB. PAPERS 1339, 1340 (Oct. 10, 1997) (emphasis added).

74. Christopher S. Yoo, Steven G. Calabresi \& Anthony Colangelo, The Unitary Executive in the Modern Era, 1945-2004, 90 IOWA L. REV. 601, 607 (2005).

75. The theory itself is quite controversial in academia, and it is probably no coincidence that Clinton did not use the term itself.

76. See supra note 41 and accompanying text.

77. E.g., Statement on Signing the Omnibus Consolidated Rescissions and Appropriations Act of 1996,1 PuB. PAPERS 636 (Apr. 26, 1996). 
legislative history unconnected to any constitutional concerns. For example, in signing the Federal Aviation Reauthorization Act in 1996, President Clinton stated:

I am very disappointed that the Congress included a controversial amendment of the Railway Labor Act in this legislation without the benefit of public debate or hearings. I have, however, signed H.R. 3539 into law because the sponsors of the amendment and the Committee of Conference have assured me that section 1223 merely restores the exact legal standards for coverage under the Railway Labor Act as they existed prior to the effective date of the ICC Termination Act of 1995. Neither the amendments to the Railway Labor Act, nor the fact that it has been amended, should be interpreted as affecting coverage under the Railway Labor Act. $^{78}$

Clinton's and Bush's signing statements have many other similarities. Clinton, like Bush, objected to numerous different provisions in large bills, such as appropriations bills. ${ }^{79}$ Both presidents interpreted statutory language narrowly in order to avoid constitutional problems, and in similar ways - for example, interpreting mandatory language as precatory. ${ }^{80}$

If Bush and Clinton rely on similar or even identical theories of executive power in their signing statements, what accounts for the difference in the frequency with which they challenge statutory provisions? One possibility is that the similar language in their statements masks important jurisprudential differences, which can be discovered only by consulting Office of Legal Counsel memoranda, litigation positions, the give-andtake with Congress reflected in letters and other formal communications, and actual presidential orders. ${ }^{81}$ This possibility is

78. Statement on Signing the Federal Aviation Reauthorization Act of 1996, 2 PUB. PAPERS 1796, 1797 (Oct. 9, 1996).

79. Compare Statement on Signing the Omnibus Consolidated and Emergency Supplemental Appropriations Act, 1999, 2 PuB. PAPERS 1843 (Oct. 23, 1998), with Statcment on Signing the Military Construction Appropriations and Emergency Hurricane Supplemental Appropriations Act, 2005, 40 WEEKLY COMP. PRES. DOC. 2385 (Oct. $13,2004)$.

80. Compare Statement on Signing the International Religious Freedom Act of 1998, 2 PUB. PAPERS 1883 (Oct. 27, 1998), with Statement on Signing the Maritime Transportation Security Acl of 20102. 38 WEEKLY COMP. PRES. DOC. 2095 (Nov. 25, 2002).

81. With respect to the Bush administration, critics would likely cite to, among other things, OLC's original torture memo and the administration's position with respect to NSA surveillance. The degree to which the administration's position in these controversies is consistent with the views of prior administrations, and the degree to which they are representative of the positions generally taken by the Bush administration with respect to executive power, are beyond the scope of this article. 
widely believed, but there are grounds for skepticism. The two Office of Legal Counsel memoranda most prominently invoked by Bush II during the current signing statements controversy were written by Clinton's Assistant Attorney General, Walter Dellinger. ${ }^{82}$ In addition, Clinton's Justice Department advanced a number of expansive interpretations of presidential powerfor example, in commenting on a bill that would have prohibited Clinton from using appropriations to fund American troops under UN command unless he informed Congress of his intention fifteen days in advance, the Office of Legal Counsel argued that such a provision violates both the commander-in-chief clause and the president's constitutional authority to conduct diplomacy. ${ }^{83}$ Until detailed comparative academic work has been done, we think it premature to assume that Bush has issued more challenges in his signing statements because he has significantly different views about executive power, though of course this may turn out to be correct. For now, the point to understand is that theories articulated in the signing statements do not themselves provide evidence that Bush and Clinton have significantly different views about the scope of executive power.

Another possibility is that Bush uses essentially the same constitutional theories as Clinton does, but applies them more systematically. Perhaps the Bush administration is like a lawyer who writes "privileged and confidential attorney work product" on every document he prepares, even when it is extremely unlikely that the document will ever be subject to discovery. The Justice Department has long made it a practice of sending "bill comments" to Congress, which object to constitutionally problematic provisions in pending bills, especially provisions that infringe on executive power. ${ }^{84}$ The bill comment practice is routine and bureaucratic; it is intended to prevent Congress from interpreting a president's silence about constitutionally problematic bills as evidence that he is yielding his powers. The practice appears to have migrated to the signing statement, perhaps because a statement issued at the signing of the bill makes clear that any problems identified earlier were never corrected.

The 9/11 effect may also be a major explanatory variable. Bush did not challenge any provisions on commander-in-chief

82. See supra note 20 and infra note 96

83. See Placing of United States Armed Forces Under United Nations Operational or Tactical Control, 20 Op. Off. Legal Counsel 182 (1996).

84. See Cornelia T.L. Pillard, The Unfulfilled Promise of the Constitution in Executive Hands, 103 MICH. L. REV. 676, 711-12 (2005). 
grounds prior to $9 / 11 .{ }^{85}$ Since $9 / 11$, he has issued thirty-six signing statements that include challenges on commander-in-chief grounds, or about five per year. Moreover, national securityrelated legislation, a significant part of the statutory landscape after $9 / 11$, is more likely to raise issues about the scope of executive power.

Even if Bush's signing statements are qualitatively different from Clinton's, the significance of this difference is open to question. Several considerations need to be addressed.

First, are the constitutional claims mostly political rhetoric or does Bush act on them? Often, he says (like other presidents) that he is not required to give notice to Congress about troop deployments but will when practicable. In practice, does Bush provide more or less notice to Congress than prior presidents have done? A related question is whether the provisions being challenged are important or trivial. As far we have found, the critics of the Bush administration's use of signing statements have not identified a single instance where the Bush administration followed through on the language in the signing statement and refused to enforce the statute as written. Christopher May has shown that presidents usually do not press the constitutional claims that they make in signing statements - often because conflicts never arise in the first place (for example, Congress does not exercise a legislative veto that the president repudiates). ${ }^{86}$

Second, are the claims justified or unjustified? This is an extremely difficult question. Clinton and Bush agree that the commander-in-chief clause restricts Congress's control of military personnel. But how great is this restriction? As a matter of constitutional theory and political morality, there is no obvious answer ${ }^{87}$ Former Clinton officials argue that Bush's views about executive power are unreasonable, whereas Clinton's were rea-

85. But there is a confounding factor, which is that presidents generally do not use signing statements aggressively in their first year, perhaps because their attention is focused on the transition from the prior administration.

86. See May, supra note 15 , at $937-45$.

87. Cf. Youngstown Sheet \& Tube Co. v. Sawyer, 343 U.S. 579, 641 (1952) (Jackson, J., concurring) ("These cryptic words [of the Commander in Chief Clause] have given rise to some of the most persistent controversies in our constitutional history."). Similarly, with respect to the unitary executive, compare Steven G. Calabresi \& Kevin H. Rhodes, The Structural Constitution: Unitary Executive, Plural Judiciary, 105 HARV. L. REV. 1153 (1992), with Lawrence Lessig \& Cass R. Sunstein, The President and the Administration, 94 COLUM. L. REV. 1 (1994). On the scope of presidential power generally compare EDWARD S. CORWIN, THE PRESIDENT: OFFICE AND Powers, 1787-1957: HISTORY AND ANALYSIS OF PRACTICE AND OPINION (4th rev. ed. 1957), with CLINTON Rossiter, THE AMERICAN PRESIDENCY (1st ed. 1956). 
sonable. ${ }^{88}$ We accept the possibility that Clinton's views and Bush's views, although similar in broad contours, differ in important respects, but it is hard to control for the different circumstances of their administrations. It is also much more difficult than the Bush critics imply to argue that one president's view is superior to the other's on normative grounds. Such an argument depends on a theory of presidential power, which is a deeply controversial subject.

Third, if Bush is indeed staking out broader constitutional claims than other recent presidents, to what extent is this simply an effort to recapture presidential authority lost in the 1970s? It has been widely reported that Vice-President Cheney has made a conscious effort to do this, and signing statements may be part of this effort. ${ }^{89}$

Finally, it is possible that other presidents have used other instruments than Bush for achieving the same ends. Perhaps, for example, other presidents may have used executive orders or formal directives where Bush uses signing statements. ${ }^{90}$ We suspect that in many cases presidents did not issue signing statements and simply refused to comply with statutory provisions that they objected to, and Congress did not object; or if Congress did object, presidents defended themselves by letter or else yielded to the pressure. If the only difference between Bush and these other presidents is that he more often stated his objections in advance in a signing statement, then this is hardly a matter of concern.

All of this suggests that the Bush administration critics' focus on signing statements is misguided. If critics seek to attack the Bush administration's views about executive power, they need to focus on other documents such as Office of Legal Counsel memoranda, and examine the administration's actions as well as its words. Presidents before Bush have staked out strong positions on executive privilege, immunity of the president to criminal indictment, and related issues; all of these positions, and actions based on them, need to be considered as well as signing

88. See, e.g., Symposium, War, Terrorism and Torture: Limits on Presidential Power in the 21st Centurty, 81 IND. L.J. 1139 (2006). But cf. JOHN YOO, WAR BY OTHER MEANS: AN INSIDER'S ACCOUNT OF THE WAR ON TERROR ch. 7 (2006) (arguing that Clinton's and Bush's views of the commander-in-chief power are the same)

89. See John Yoo, Editorial, How the Presidency Regained its Balance, N.Y. TIMES, Sept. 17, 2006, $\$ 4$, at 15 .

90. See, e.g., Kagan, supra note 14, at 2285-99 (documenting Clinton Administration's frequent use of orders and directives). 
statements. If the critics believe that the signing statement itself is constitutionally problematic, then they should not focus on Bush. They should complain about the signing statement practices of Clinton, Reagan, Truman, FDR, and even James Monroe. But we will not let this inconsistency prevent us from inquiring into the legal and normative basis of the signing statement critique, the subject of Parts III and IV.

\section{LEGAL CRITIQUES OF SIGNING STATEMENTS}

Critics have questioned the legality of presidential signing statements when they are used for purposes other than political rhetoric. In this Part, we consider the principal legal arguments that have been made against signing statements. As we explain, most of the legal arguments boil down to either disagreement with the perceived substantive claims being made in the statements or a concern about judicial deference to the claims and therefore do not provide a basis for concluding that the statements themselves are legally problematic. In this Part, we address the legal issues. Many critics also suggest that the phenomenon of signing statements has negative institutional effects - for example, on the balance of power between the legislative and executive branches--without necessarily suggesting that these negative effects result in illegality. We address these institutional arguments separately in Part IV.

\section{A. Constitutional Signing Statements}

Critics have raised several legal objections to constitutional signing statements - that is, statements in which the president raises constitutional concerns about bills that the president has signed. Before considering these objections, we need to highlight a preliminary issue that relates to these objections. The issue is whether the president has a constitutional duty to enforce laws that he believes are unconstitutional.

Commentators are divided over this issue. ${ }^{91}$ Some commentators argue that presidents must always enforce a statute, regardless of whether they believe it to be constitutional, unless and until courts hold that the statute is unconstitutional. ${ }^{92}$ Other

91. See Dawn E. Johnsen, Presidential Non-Enforcement of Constitutionally Objectionable Statutes, 63 LAW \& CONTEMP. ProBS. 7, 14-22 (Winter/Spring 2000) (describing the debate).

92. See, e.g., Eugene Gressman, Take Care, Mr. President, 64 N.C. L. REv. 381 (1986); May, supra note 15; Arthur S. Miller, The President and Faithful Execution of the 
commentators argue that in the absence of a judicial resolution of the issue, presidents have no obligation to enforce a statute that they believe to be unconstitutional - and, indeed, may have an obligation not to enforce the statute. ${ }^{93}$ Still other commentators argue for an intermediate position whereby presidents may sometimes disregard statutes that they believe to be unconstitutional, such as when a statute violates a Supreme Court precedent or invades executive power. ${ }^{94}$ There is also a related debate over the extent to which presidents should presume statutes to be constitutional. ${ }^{95}$

Perhaps not surprisingly, presidents have often claimed the authority to disregard statutes that they believe to be unconstitutional. As Walter Dellinger has noted, executive branch "[o]pinions dating to at least 1860 assert the President's authority to decline to effectuate enactments that the President views as unconstitutional." 96 Even before that, there are examples of presidents declining to enforce statutes because of constitutional concerns - for example, Jefferson declined to continue prosecutions under the Sedition Act because of First Amendment concerns. ${ }^{97}$ In the modern era, both Republican and Democratic presidents have claimed that they are not bound by provisions in the War Powers Resolution because these provisions unconstitutionally infringe on the commander-in-chief clause or - what is the same thing-have interpreted the Resolution narrowly so as not to constrain them. ${ }^{98}$ Another, less controversial example is

Laws, 40 VAND. L. REV. 389, 395-98 (1987).

93. See, e.g., Frank H. Easterbrook, Presidential Review, 40 CASE W. REs. L. REV. 905 (1990); John Harrison, The Constitutional Origins and Implications of Judicial Review, 84 VA. L. ReV. 333 (1998); Gary Lawson \& Christopher D. Moore, The Executive Power of Constitutional Interpretation, 81 IowA L. REV. 1267 (1996); Michael Stokes Paulsen, The Most Dangerous Branch: Executive Power to Say What the Law Is, 83 GEO. L.J. 217 (1994); see also David Barron et al., Untangling the Debate on Signing Statements, http://gulcfac.typepad.com/georgetown_university_law/2006/07/thanks_to_the_p. html (July 31, 2006).

94. See, e.g., Johnsen, supra note 91.

95. See, e.g., id. at 35 (arguing for presumption of constitutionality).

96. See Memorandum from Walter Dellinger, Assistant Attorney Gen., Office of Legal Counsel, to the Honorable Abner J. Mikva, Counsel to the President para. 3 (Nov. 2, 1994), available at http://www.usdoj.gov/olc/nonexcut.htm.

97. See Letter from Thomas Jefferson to Edward Livingston (Nov. 1, 1801), in 8 ThE WRITINGS OF THOMAS JEFFERSON 57, 58 (Paul Leicester Ford ed., 1897) ("I affirm that act to be no law, because in opposition to the constitution; and I shall treat it as a nullity, wherever it comes in the way of my functions.").

98. See Richard F. GRIMMETt, CONG. Research SERVICE, War Powers RESOlution: PRESIDENTIAl COMPlianCE CRS-2 (Nov. 15, 2004) ("[S]ince the War Powers Resolution's enactment, over President Nixon's veto in 1973, every President has taken the position that it is an unconstitutional infringement by the Congress on the President's authority as Commander-in-Chief."), available at http://www.fas. 
the frequent statement by presidents that they are not bound by one-house or legislative committee veto provisions, in light of the Supreme Court's decision in Chadha. ${ }^{99}$ On several occasions in different administrations, the Attorney General or the Justice Department's Office of Legal Counsel has expressed the view that presidents may decline to enforce unconstitutional statutes. ${ }^{100}$ Equally unsurprisingly, Congress has sometimes contested the proposition that the president may refuse to enforce statutes that he views as unconstitutional. Indeed, the asserted basis for impeaching (and almost convicting) President Andrew Johnson was his refusal, on constitutional grounds, to comply with the Tenure of Office Act, which was enacted over his veto. ${ }^{101}$

The Supreme Court has not definitively addressed this issue, although some of its decisions and statements could be read as providing modest support for a presidential power to disregard at least some unconstitutional statutes. Justice Jackson's celebrated concurrence in Youngstown assumes that under some circumstances courts will uphold presidential actions "incompatible with the expressed or implied will of Congress," although such actions will be "scrutinized with caution." 102 In Myers v. United States, the Court agreed with the President that a statute that required Senate approval for removal of the postmaster was unconstitutional, and the Court did not comment negatively on

$\mathrm{org} / \mathrm{man} / \mathrm{crs} / \mathrm{IB} 81050 . \mathrm{pdf}$; Proposed Deployment of United States Armed Forces into Bosnia, 19 Op. Off. Legal Counsel 327 (Nov. 30, 1995) ("The Executive Branch has traditionally taken the position that the President's power to deploy armed forces into situations of actual or indicated hostilities is not restricted to the three categories specifically marked out by the Resolution.").

99. Even before Chadha, a number of presidents had expressed the view that they were not bound by legislative veto provisions. See Paulsen, supra note 93, at 267.

100. See, e.g., Memorandum from Walter Dellinger, supra note 96; Issues Raised by Provisions Directing Issuance of Official or Diplomatic Passports, $16 \mathrm{Op}$. Off. Legal Counsel 18 (1992), available at http://www.usdoj.gov/olc/gray.11.htm; Issues Raised by Foreign Relations Authorization Bill, 14 Op. Off. Legal Counsel 37 (1990); Constitutionality of Congress' Disapproval of Agency Regulations by Resolutions Not Presented to the President, 4A Op. Off. Legal Counsel 21 (1980) (opinion on Attorney General Benjamin R. Civiletti).

101. See William H. Rehnouist, Grand Inouests: THE Historic IMPEACHMENTS OF JUSTICE SAMUEL CHASE AND PRESIDENT ANDREW JOHNSON 22627 (1992).

102. Youngstown Sheet \& Tube Co. v. Sawyer, 343 U.S. 579, 637-38 (1952) (Jackson, J., concuring). The much-discussed footnote 23 in the recent Hamdan decision is not inconsistent with this proposition: it states that the president may not disregard limitations enacted by Congress "in proper exercise of its own war powers," suggesting that the president may be able to disregard limitations imposed by Congress that exceed its war powers. See Hamdan v. Rumsfeld, 126 S. Ct. 2749, 2774 n.23 (2006). 
the President's refusal to comply with that statute. ${ }^{103}$ And four Justices in Freytag $v$. Commissioner stated in passing that the president has the power "to disregard [laws encroaching on his authority] when they are unconstitutional."104

We take no position on this issue because it is orthogonal to the legality of constitutional signing statements. If it is proper for presidents to at least sometimes refuse to enforce statutes that they think are unconstitutional, then announcing such an intention in a signing statement cannot be illegal, and indeed it may be desirable to have the president state his intention in this regard at the earliest possible moment so that Congress and potential litigants can take it into account. ${ }^{105}$ Of course, presidents will sometimes make invalid assertions of unconstitutionality, and they may have an incentive to take aggressive positions with respect to presidential power in particular. This simply means, however, that the substantive views expressed in signing statements will sometimes be legally problematic, not that the phenomenon of signing statements is itself legally problematic. On the other hand, if one believes that presidents should never decline to enforce statutes based on an assertion of unconstitutionality, then one will also believe that they should not issue signing statements claiming this authority. But the problem here will be the underlying views expressed in the statements, not the state-

103. 272 U.S. $52(1926)$.

104. 501 U.S. 868, 906 (1991) (Scalia, J., concurring in part and concurring in the judgment). Two circuit courts (one in a withdrawn opinion and the other in dicta) have expressed the view that the president has a duty to enforce statutes that he believes to be unconstitutional. See Ameron, Inc. v. U.S. Army Corps of Engineers, 809 F.2d 979 (3d Cir. 1986); Lear Siegler v. Lehman, 842 F.2d 1102 (9th Cir. 1988), withdrawn in part, 893 F.2d 205 (9th Cir. 1989).

105. Congress has enacted a statute providing that:

The Attorney General shall submit to the Congress a report of any instance in which the Attorney General or any officer of the Department of Justice ... establishes or implements a formal or informal policy to refrain ... from enforcing, applying, or administering any provision of any Federal statute ... whose enforcement, application, or administration is within the responsibility of the Attorney General or such officer on the grounds that such provision is unconstitutional ....

28 U.S.C. $\$ 530 \mathrm{D}(\mathrm{a})(1)(2006)$. Such a report must be made within 30 days after the policy is implemented, and must "include a complete and detailed statement of the relevant issues and background (including a complete and detailed statement of the reasons for the policy or determination... )." Id. $\$ 530 \mathrm{D}(\mathrm{c})(2)$. In signing the latest version of this statute, President Bush stated that "[t]he executive branch shall construe [this section and related provisions] in a manner consistent with the constitutional authorities of the President to supervise the unitary executive branch and to withhold information the disclosure of which could impair foreign relations, the national security, the deliberative processes of the Executive, or the performance of the Executive's constitutional duties." Statement on Signing the 21st Century Department of Justice Appropriations Authorization Act, 38 WEEKLY COMP. PRES. DOC. 1971, 1971 (November 2, 2002). 
ments themselves. ${ }^{106}$ Moreover, even if presidents accepted the view that they had to enforce all statutes, constitutional signing statements could still play a useful informational role-for example, presidents could use them to state that they were enforcing a statute under protest, and perhaps also to direct executive branch lawyers not to defend the constitutionality of the statute in litigation.

With these points in mind, we now consider the legal objections to constitutional signing statements. One argument is that these statements constitute an abuse of the veto process set forth in the Constitution. ${ }^{107}$ The Presentment Clause of the Constitution provides that bills that are approved by the House and Senate shall be presented to the president and that, if he approves the bill "he shall sign it, but if not he shall return it, with his Objections to the House in which it shall have originated." president returns a bill, Congress then has the constitutional authority to enact the bill into law over the president's objection upon a two-thirds vote in both Houses. ${ }^{109}$ The president improperly circumvents this process, the argument goes, if he signs a bill and then states in a signing statement that he has constitutional objections to it. In that situation, unlike with a veto, the bill is not returned to Congress to give it an opportunity to enact the bill into law over the president's objection.

This argument is unpersuasive, for several reasons. First, in the signing statement, the president is not purporting to use his presidential authority to block enactment of the law, which is what happens with a veto. Instead, he is claiming that the Constitution itself blocks the law from taking effect. He may or may not be right about such a claim, but his position is different from when he exercises a veto. For example, unlike with a veto, the president cannot validly use a signing statement to announce that he will not enforce a statute merely because he disagrees with it as a matter of policy.

Second, the effect of the signing statement is also different from that of a veto. Among other things, the statute remains on the books, available for application by courts (if they find it to be

106. Some critics are concerned that signing statements will make it easier for presidents to assert non-enforcement authority. See, e.g., Epstein, supra note 10. No one has explained why this might be so, however.

107. See, e.g., ABA TASK FORCE, supra note 11, at 18-19; May, supra note 15; Bruce Fein, Commentary, Great Usurpations, WASH. TIMES, Aug. 1, 2006, at A15.

108. U.S. CONST, art. I, $\$ 7, \mathrm{cl} .2$.

109. Id. 
constitutional) or by a subsequent president with different constitutional views. By contrast, a bill that is vetoed never becomes law, for either the courts or the executive, unless and until it is reenacted by a supermajority of Congress.

Third, it is unlikely that a constitutional signing statement changes the outcome that would result if the bill were instead returned to Congress and then reenacted over the president's veto. In either case, if the president believes that he should not execute unconstitutional laws, then he will not do so.

Finally, the president and his subordinates can uncontroversially announce their views about the constitutionality of a statute in other contexts - in internal communications within the executive branch, for example. Indeed, the Justice Department's Office of Legal Counsel does this routinely. It is difficult to see why it suddenly becomes legally problematic for the president to state such views in a signing statement.

A related argument is that constitutional signing statements constitute improper "line-item" vetoes. ${ }^{110}$ The Supreme Court has held that a line-item veto, whereby a president cancels or alters legislation after it is enacted, is unconstitutional even if approved in advance by Congress. ${ }^{111}$ When he states in a signing statement that he will not give effect to a statutory provision because he believes it to be unconstitutional, the argument goes, he is in effect exercising a line-item veto. Indeed, unless his objection relates to the entire bill in all of its applications, which is unlikely, then the president can be seen as accepting the portions of the legislation that he approves and canceling those portions that he disapproves, or "cherry-picking" the legislation, which is exactly what would happen with a line-item veto.

This argument is also unpersuasive, for essentially the same reasons why the veto abuse argument is weak. When the president issues a constitutional signing statement, he is not purporting to use any executive authority to cancel all or part of a statute. He is making a claim about the effect of the Constitution on

110. See, e.g. Time Change, supra note 41 (statement of Bruce Fein, Partner, Fein \& Fein); COOPER, supra note 16, at 203-06 (describing certain uses of signing statements as fiscal and substantive line-item vetoes); Cooper, Use and Abuse, supra note 10, at 531 (asscrting that signing statements "can and have been used as line-item vetoes of legislation presented to the president for signature or veto but without the use of the formal veto or the opportunity for legislative override processes"); see also Lear Sicgler v. Lehman, 842 F.2d 1102, 1124 (9th Cir. 1988), withdrawn in part, 893 F.2d 205 (9th Cir. 1989); ABA TASK FORCE, supra note 11, at 18.

111. See Clinton v. New York, 524 U.S. 417, 421 (1998). 
the legal effect of the statute. He may also be signaling his unwillingness to enforce a statutory provision that he believes is unconstitutional in the absence a judicial resolution of the matter, something that he could do outside the context of a signing statement. If it is improper for him to decline to enforce a statute in that situation (an issue on which, as discussed above, we take no position), then it will be improper regardless of the signing statement. Conversely, if this is a proper course of action, it is hard to see how making that intention clear in a signing statement renders it illegal; indeed, one might think that generally it is better for the president to make clear his views in this regard so that Congress can react if it so wishes. ${ }^{112}$

Moreover, whether a president's refusal to enforce a statute will have the effect of preventing a provision from being enforced will depend on a variety of factors, including the availability of judicial review. If judicial review is available, courts will make their own assessment of the president's constitutional argument, and they are unlikely to give substantial deference to the president's views of the Constitution. If they nevertheless agree with the president's argument, then it will be the judges' construction of the Constitution, not the political authority of the president, that nullifies the provision, and the courts can also make a judgment about whether the provision is severable from the rest of the legislation. In the absence of judicial review, the matter will be resolved, like most separation of powers issues, through the political process. It is not clear that the mere fact of the signing statement will affect how that process comes out, and certainly critics have not presented any empirical evidence showing such an effect.

A different (and better) version of the veto abuse argument and the line-item veto argument is the claim that the president has a constitutional duty to veto statutes he believes to be unconstitutional. The argument here is that the president's oath of office and the Take Care Clause require him to enforce the Constitution, and that he violates this duty if he signs into law a statute that he believes to be unconstitutional. ${ }^{113}$ Under this argu-

112. To be sure, not all signing statements are clear. Some of them are vague, and we are not claiming that Bush or any other president has used signing statements in some sort of ideal way. Even the vague ones, however, provide more information than silence would. Moreover, vagueness may also reduce the effect of a signing statement on the actions of executive branch subordinates in implementing a statute, something critics are concerned about.

113. See, e.g., ABA TASK FORCE, supra note 11, at 19 
ment, it may be proper for a president to decline to enforce a statutory provision that he believes to be unconstitutional if it was signed into law by a predecessor or enacted over his veto, or if he discovers the constitutional problem only after enactment, but he should never sign a bill into law if he believes at that time that it has an unconstitutional provision. This argument has some formal appeal, although it is subject to the counterargument that the president's act of signing does not give the provision legal effect, since an unconstitutional law has no legal effect. As a result, as long as he makes clear that he is not sanctioning the unconstitutional provision, the president is not violating his oath to uphold the Constitution merely by the act of signing; rather, he would violate his oath only if he enforced the unconstitutional provision. Signing and enforcement, in other words, may not be formally comparable. ${ }^{114}$ To be sure, if a president believed that all or most of bill was unconstitutional, the argument for some sort of duty to avoid sanctioning the bill through signature would be stronger, although this scenario rarely comes up. In any event, we believe that the argument that a president must always veto a bill if it has what he believes to be an unconstitutional provision is unrealistic in an age of omnibus legislation: presidents are often presented with dozens and even hundreds of provisions in a bill, often on multiple subjects, and as a political matter they will not be able to veto such bills simply because of constitutional concerns about a particular provision. ${ }^{15}$ The argument is particularly unrealistic once it is remembered that the asserted unconstitutionality often relates merely to possible applications of the provision. ${ }^{16}$

Critics also have challenged the invocation of constitutional concerns in signing statements to justify particular statutory interpretations. When presidents have constitutional concerns, it is rare for them to announce in a signing statement that they will decline to enforce a statutory provision. Instead, they frequently

114. Some people have argued that if the president can sign laws with provisions that he believes unconstitutional despite his oath, then Congress would be able to enact laws it believes unconstitutional despite the members' oaths. It is not clcar that this would be a problem-Congress could simply expect the president and courts to refuse to give legal effect to laws found to be unconstitutional-but in any event the president has a better argument that he respects his oath by refusing to enforce unconstitutional provisions, whereas Congress has no such instrument for depriving its enactments of effect.

115. On the rise of omnibus legislation, see David R. MAYHEW, Divided WE GOVERN: PARTY CONTROL, LAWMAKING, AND INVESTIGATIONS, 1946-2002, 70-80 (2d ed. 2005). It may be that some phenomenon (such as decentralization in Congress) has contributed both to the rise of omnibus legislation and the rise of signing statements.

116. See Barron et al., supra note 93. 
state that they will interpret the provision in a way that will avoid the purported constitutional problem. With respect to the ban on cruel, inhuman, or degrading treatment of detainees contained in the Detainee Treatment Act, for example, President Bush stated that the executive branch would construe the ban "in a manner consistent with the constitutional authority of the President to supervise the unitary executive branch and as Commander in Chief and consistent with the constitutional limitations on the judicial power."117 Critics contend that this practice allows presidents to distort the meaning of statutes and thereby in effect disregard or change them.

In considering this objection, it is useful to distinguish between situations in which a statute is truly ambiguous, and situations in which the president is purporting to interpret a statute when in fact his interpretation is contrary to its plain meaning. When a statute is truly ambiguous, it is difficult to see how it is legally objectionable for a president to adopt an interpretation that avoids constitutional concerns. ${ }^{118}$ The Supreme Court regularly applies such a constitutional avoidance canon when it construes statutes. ${ }^{119}$ One might object that merely invoking constitutional "concerns" allows the president to disregard a greater number of statutory provisions than if he had to take a firm position on its constitutionality. This problem has been noted with respect to judicial reliance on the constitutional avoidance canon. The objections to that canon as used by the courts, however, are less applicable to the president. Critics have noted that judicial underenforcement of statutes based on constitutional concerns will often be contrary to what Congress would have

117. Statement on Signing the Department of Defense, Emergency Supplemental Appropriations to Address Hurricanes in The Gulf of Mexico, and Pandemic Influenza Act, 2006, 41 WEEKLy COMP. PRES. DOC. 1918, 1919 (Dec. 30, 2005).

118. For such a claim, however, see H. Jefferson Powell, The Executive and the Avoidance Canon, 81 IndianA L.J. 1313, 1316 (2006). Powell contends that the judicial avoidance canon limits the judiciary's authority whereas the executive's use of the avoidance canon cnhances the executive's authority. A problem with this argument is that it assumes particular baselines. Powell assumes that if a court did not use the canon it would have to strike down statutes, whereas if the executive did not use the canon it would have to enforce the statute. But we could switch baselines and start with the assumption that without such a canon the judiciary would strike down only clearly invalid statutes and that without such a canon the executive would refuse to obey ambiguously invalid statutes. For additional discussion of the use of the avoidance canon by the executive branch, see Trevor W. Morrison, Constitutional Avoidance in the Executive Branch, 106 COLUM. L. REV. 1189 (2006).

119. See, e.g., Harris v. United States, 536 U.S. 545, 555-56 (2002); Communications Workers v. Beck, 487 U.S. 735,762 (1988). 
wanted. ${ }^{120}$ Unlike the courts, however, the president is a participant in the enactment of legislation, as well as the actor responsible for enforcement of the legislation, so he has a stronger claim than the courts to decide on underenforcement. Indeed, outside the context of signing statements, the executive branch in a host of situations uncontroversially decides on the level of enforcement of statutory provisions. ${ }^{121}$

Moreover, for many of the constitutional interpretive statements, it is not clear that there will even be underenforcement. Many of the statements appear simply to be placeholders to preserve an executive viewpoint about the Constitution, not an indication that the executive will decline to fully enforce a statute. ${ }^{122}$ Indeed, some of them specifically note that, despite the alleged constitutional problems, the executive will enforce the statute "as a matter of comity." 123 And many statements, perhaps most, address contingencies that might never arise. For example, when the president invokes the commander-in-chief clause in order to justify interpreting a statutory reporting obligation so that it does not interfere with national security, he does not thereby announce that he will ignore the law, because the reporting requirement may never conflict with national security. Similarly, the controversial statement for the Detainee Treatment Act does not assert that that the President will ignore the law. Even in situations in which he believes that he has the constitutional authority to disregard the Act, he (or his subordinates) might nevertheless comply with it for policy reasons. ${ }^{124} \mathrm{As}$

120. See, e.g., Frederick Schaucr, Ashwander Revisited, 1995 SUP. CT. REV. 71

121. See, e.g., Heckler v. Chaney, 470 U.S. 821 (1985) (finding that agency decisions not to exercise enforcement authority are presumptivcly not subject to judicial review); Teah R. Lupton, Prosecutorial Discretion, 90 GEO. L.J. 1279, 1283-84 (2002) (discussing the limited constraints on prosecutorial discretion).

122. See Presidential Signing Statements, supra note 41 (statement of Michelle E. Boardman) ("Many constitutional signing statements are an attempt to preserve the enduring balance between co-equal branches, but this preservation does not mean that the President will not enforce the provision as cnactcd."); Savagc, supra note 6, at A1 ("Nothing in the world changes by the publication of a signing statement. The statements merely serve as public notice about how the administration is interpreting the law." (quoting Jack Goldsmith, former head of the Office of Legal Counsel)).

123. E.g., Statement on Signing Legislation to Address the Participation of Taiwan in the World Health Organization, 40 WEEKLY COMP. PRES. DOC. 1070 (Jun. 14, 2004); Statement on Signing the Strengthen AmeriCorps Program Act, 39 WEEKLY COMP. PRES. DOC. 876 (July 3, 2003); Statement on Signing Legislation Concerning Participation of Taiwan in the World Health Organization, 39 WEEKLY COMP. PRES. DOC. 679 (May 29, 2003).

124. According to news reports, after the enactment of the Detainee Treatment Act, the Central Intelligence Agency largely halted its overseas interrogation program for high-level terrorist suspects. See Guy Dinmore, CIA Forced Bush Hand on Secret Pris. 
a result, it is not clear that a higher number of constitutional signing statements correlates with increased presidential noncompliance with statutes. Richard Epstein has argued that signing statements could be the "opening wedge to a presidential posture that judicial decisions may limit the president's ability to use courts to enforce his policies, but cannot stop him from acting unilaterally." 125 But Epstein cites no evidence that Bush, who has been in office for more than five years, has begun acting unilaterally in a way that is contrary to judicial decisions, and Bush's decision to comply with decisions like Hamdan suggest the contrary. Applying an "opening wedge" argument to Bush is also odd; such an argument would have been more appropriately applied to Reagan or to an even earlier president who used signing statements, and yet the general growth of executive power aside, no one thinks that earlier signing statements have enabled presidents to ignore judicial decisions.

\section{B. INTERPRETIVE SIGNING STATEMENTS}

Interpretive (or legislative history) signing statements also have generated controversy. Critics contend that, if courts give weight to these interpretive statements, it will undermine separation of powers. ${ }^{126}$ Giving weight to these statements, the argument goes, will in effect allow the president to legislate without following the process for legislation set forth in Article I of the Constitution. Relatedly, critics suggest that if courts give weight to signing statements, the president will in effect have the ability to exercise a veto over legislation without being subject to having the veto overridden as provided for in Article I, or will in effect be exercising a line-item veto ${ }^{127}$ Alternatively, critics contend that if courts give weight to interpretive signing statements they will be improperly abdicating their authority to interpret the law. ${ }^{128}$ Consequently, the critics argue, signing statements "should be given no weight by a court when interpreting the intent of Congress." 129

There are a number of problems with this argument. As an initial matter, it is important to note that the argument is not an

\footnotetext{
ons, Financial Times, Sept. 21, 2006, at 1.

125. Epstein, supra note 10.

126. See, e.g., Garber \& Wimmer, supra note 1; William D. Popkin, Judicial Use of

Presidential Legislative History: A Critique, 66 IND. L.J. 699 (1991).

127. Garber \& Wimmer, supra note 1 , at $375-76$

128. Id. at $384-85$.

129. Id. at 368 .
} 
objection to signing statements per se. Rather, the objection is to the possibility that courts will give weight to such statements when interpreting statutes. It is not clear at this point, however, whether and to what extent courts will give weight to these statements. ${ }^{130}$ Nor have presidents claimed that the signing statements are controlling on the courts. ${ }^{131}$ In addition, the argument fails to distinguish between various degrees of weight that courts might give to signing statements. We are not aware of anyone who argues that these statements should be dispositive or should trump clear statutory language. The real issue, therefore, is whether they should be given some weight when statutory meaning is otherwise ambiguous, in the same way that courts often give weight to pre-enactment statements by members of Congress or congressional committees. If one concludes that signing statements are a relevant piece of evidence concerning statutory meaning, then relying on such statements would not amount to a veto or alteration of the legislation.

Moreover, the proposition that it violates separation of powers for courts to give any weight to statutory interpretations by the executive that are announced after a bill is signed into law is in tension with modern administrative law. Courts routinely give deference to post-enactment statutory interpretations by executive branch agencies-under the Chevron and Skidmore doctrines, for example. Courts give this sort of deference to executive agencies because of their expertise and because Congress often expects that agencies will fill in gaps and ambiguities in enactments. Moreover, courts reason that if Congress disagrees

130. In Hamdan v. Rumsfeld, 126 S. Cl. 2749 (2006), the Supreme Court majority did not even mention, let alone give weight to, the President's interpretation of the Detainee Treatment Act in his signing statement, as Justice Scalia pointed out in his dissent. See id. at 2816 (Scalia, J., dissenting). A survey of judicial opinions with the phrase "signing statement" in them suggests that courts cite them to bolster an interpretation of Congress's intent for which there is other evidence in the legislative history but do not give them much, if any, independent weight. See, e.g., Bowsher v. Synar, 478 U.S. 714, 719 n.1 (1986) (noting without comment that President's signing statement expressed view that act is unconstitutional); United States v. Perlaza, 439 F.3d 1149, 1163 (9th Cir. 2006) (noting that Clinton statement is consistent with conference report); United States v. Gonzalez, 311 F.3d 440, 443 \& n.2 (1st Cir. 2002) (same); Newdow v. U.S. Congress, 328 F.3d 466, 488 (9th Cir. 2003) (citing Eisenhower signing statement and other legislative history to show that pledge statute was mcant to be coercive); Clinton v. Babbitt, 180 F.3d 1081, 1087 n.4 (9th Cir.1999) (citing signing statement for meaning of statute in dicta); United States v. Story, 891 F.2d 988, 994(2d Cir. 1989) (using a Reagan signing statement, among other factors, to resolve conflicting interpretations in the House and Senate legislative history); Chrysler Corp. v. Schlesinger, 565 F.2d 1172, 1181 n.38 (3d Cir. 1977) (noting that signing statement is consistent with House report).

131. See Presidential Signing Statements, supra note 41 (statement of Michelle E Boardman) ("Signing statements, of course, are not binding on the courts ...."). 
with the agency's interpretation, it has the ability to override the interpretation through new legislation. These justifications will likely apply to at least some interpretive signing statements. ${ }^{132}$

In addition, critics of signing statements do not contend that it violates separation of powers for courts to give weight to congressional materials when interpreting statutes. ${ }^{133}$ Instead, they argue that signing statements should not be considered because these statements, unlike congressional materials, do not help reveal the intent of members of Congress. ${ }^{134}$ It is not clear from the text or structure of the Constitution, however, why the views of the president are not relevant to the interpretation of legislation. Article I provides that, absent a supermajority, Congress cannot enact legislation without the signature of the president. In light of the difficulty of overriding a presidential veto, this means that for most legislation the president is a necessary partner with Congress in the enactment process. Since legislation reflects an agreement between Congress and the president, the president's views about the agreement would seem to be as relevant as Congress's views. ${ }^{135}$

To be sure, at the signing statement stage, the president may have more ability to engage in cheap talk than a legislator commenting on a bill, because signing statements occur after enactment and thus after Congress can revise the bill in reaction to the statement. A better argument against giving weight to inter-

132. See Cross, supra note 1. Some scholars argue that interpretive authority is granted to the relevant agency, not to the president. See, e.g., Kevin M. Stack, The President's Statutory Powers to Administer the Laws, 106 CoLuM. L. REV. 263 (2006). Even if this is correct, the agency head surely benefits from knowing the president's views as his job might depend on them, and agencies undoubtedly receive and respond to direction from the president.

133. Some commentators and judges do argue that it is improper to look at legislative history when interpreting a statute. See, e.g., ANTONin SCALIA, A MATTER OF INTERPRETATION: FEDERAL COURTS AND THE LAW 29-30 (1997). Presumably these commentators and judges would also disapprove of looking at presidential signing statements when interpreting a statute. See, e.g., Presidential Signing Statements, supra note 41 (statement of Prof. Nicholas Quinn Rosenkranz, Georgetown Law Center) (arguing that "the project of statutory interpretation is to discern "the original meaning of the text, not what the original draftsmen intended," and that "presidential signing statements-like legislative history-are of very little use in that project").

134. Garber \& Wimmer, supra note 1, at $370,392$.

135. See Cross, supra note 1, at 218 ("[S]o long as the President influences legislation, there is persuasive reason for courts to consider the text of presidential signing statements."); see also William N. Eskridge, JR., Philip P. Frickey \& ElizabeTH GARRETT, CASES AND MATERIALS ON LEgISLATION: STATUES AND THE CREATION OF PLBLIC POLICY 996 (3d ed. 2001) (noting that, "for the same reasons that interpreters are usually interested in the views of the congressional sponsors, they might be interested in the views of the President, who effectively sponsors much major legislation") 
pretive signing statements, therefore, is that they are unreliable indicators of presidential understandings of statutory meaning, and that they should be given no more weight than postenactment statements by members of Congress, which the Supreme Court has said provide "an extremely hazardous basis for inferring the meaning of a congressional enactment." dress this argument below in Part IV in comparing signing statements with pre-enactment legislative history.

If courts do not give weight to interpretive signing statements, it is difficult to see how they could be legally objectionable. By necessity, the executive branch must interpret statutes in order to implement and enforce them. ${ }^{137}$ The president must also interpret statutes in order to supervise the executive branch. If the president did not issue signing statements, he would simply use other vehicles for statutory interpretations, and those other vehicles would be less contemporaneous with the enactment of the legislation and often less public. Critics of executive power, however, usually favor greater transparency.

\section{INSTITUTIONAL ANALYSIS}

In this part, we consider signing statements from an institutional perspective. Should presidents be criticized for and discouraged from using signing statements? To answer this question, one must identify the damage that signing statements do to the constitutional system. One might show, for example, that legislative outcomes in a world without signing statements would be better than legislative outcomes in the world that we have. Unfortunately, given scholars' limited understanding of how American political institutions work, and the existence of serious controversies about how they should work, we cannot do more than provide a sketch of what a defense of signing statements would look like. But we think that this sketch should be enough to throw the burden back on the critics, who also need to overcome the presumption in favor of signing statements given the lawfulness of signing statements and their historical pedigree.

136. Consumer Product Safety Comm'n v. GTE Sylvania, Inc., 447 U.S. 102, 118 \& n.13 (1980); see also, e.g., ESKRIDGE, FRICKEY \& GARRETT, supra note 135, at 996 (noting "problems of reliability" with signing statements).

137. See Bowsher v. Synar, 478 U.S. 714, 733 (1986) ("Interpreting a law enacted by Congress 10 implement the legislative mandate is the very essence of 'execution' of the law."); Easterbrook, supra note 93. 
We will start with some basic assumptions that we take from the most sophisticated work on legislative institutions and statutory interpretation, the literature on positive political theory (PPT). It turns out that many authors writing in this literature disapprove of signing statements, so we will take their argument as our foil. After describing the general approach of the literature to statutory interpretation, we will discuss the critics' argument. We then show that this argument is sustainable only on narrow and implausible or controversial assumptions. PPT, in fact, shows that signing statements do not raise distinctive problems in comparison with other legislative and executive documents.

\section{A. BACKGROUND}

The PPT literature treats statutes as the outcome of bargains among various political actors who comprise the "enacting coalition." The enacting coalition consists of those parties whose approval was necessary for the enactment of the statute. Who belongs to the enacting coalition depends heavily on context, but roughly one can say that the coalition excludes people who vote against the bill and the extreme supporters whose preferences were not shared by those whose votes were necessary to create a majority. The coalition will also usually include committees whose approval is needed for a vote on the floor, the median voter in each house, and the president, unless he vetoed the bill and his veto was overridden. ${ }^{13}$

The members of the enacting coalition play the role that contract parties do in the economic analysis of contract law. In the contracts literature, scholars assume that the contracting parties seek to make an agreement that maximizes the value of the relationship. A hypothetical, complete contract would assign rights and obligations for every possible contingency in a manner that maximizes value. Because of transaction or bargaining costs, however, the parties must leave "gaps" in the contract. The role of the court is to fill these gaps in a manner that maximizes the ex ante value of the contract--or, what is usually the same thing, that provides the parties what they would have bargained for if

138. We are simplifying; for the full story, see McNoligast, Legislative Intent: The Use of Positive Political Theory in Statutory Interpretation, 57 LAW \& CONTEMP. PROBS. 3, 21 (Winter/Spring 1994); McNollgast, Positive Canons: The Role of Legislative Bargains in Statutory Interpretation, 80 GEO. L.J. 705, 722-25 (1992). (McNollgast is the collective name used by Matthew McCubbins, Roger Noll, and Barry Weingast when writing together.) 
they had anticipated, and bargained over, the contingency. One can similarly view legislation as having gaps because members of the enacting coalition cannot anticipate and bargain over all possible contingencies that affect the value of the legislative deal. If the analogy to contract law is right, then courts should fill the legislative gaps with the terms of a similar hypothetical bargain - the terms that the parties would have chosen because they maximize the value of the legislative deal. ${ }^{139}$

There are important differences between the contractual and legislative settings. One can more reasonably assume that a deal that receives the consent of both contracting parties enhances their welfare and, externalities aside, therefore social welfare as well, than that a legislative deal that receives the consent of members of the enacting coalition-a majority or perhaps supermajority of a group who very imperfectly represent the interests of the public-maximizes social welfare. Nonetheless, the assumption that courts should fill legislative gaps with terms that the enacting coalition would have wanted rests on two plausible considerations. First, our political system is built on the assumption that Congress makes good law-or, at least, that new law is generally superior to the status quo. Courts do not have the authority to reject this assumption. Second, if courts did not enforce legislative intent when gaps exist, then Congress would respond by passing new, more detailed laws. The additional bargaining and drafting costs would produce no offsetting benefits. ${ }^{140}$

McNollgast and other authors argue that the enacting coalition's intention - a compromise of everyone's most preferred version of the law-should be considered the meaning of the statute. However, the statements of the members of the enacting coalition during the legislative process do not necessarily reveal the coalition's intention. The problem is that often a member lacks an incentive to disclose the compromise meaning of the bill. A person who preferred a more extreme or moderate version of the bill would like courts to interpret the compromise language in the more extreme or moderate way. If the courts rely on legislative history, that person has an incentive to insert statements in the legislative history with his preferred meaning.

139. See McNollgast, Positive Canons, supra note 138, at 708-15.

140. On the other hand, if courts cannot reliably determine legislative intent, then they should refuse to fill gaps, thus encouraging Congress to write more detailed statutes. See AdRIAN VERMEULE, JUdgING UNDER UNCERTAINTY: AN INSTITUTIONAL THEORY OF LEGAL INTERPRETATION (2006). 
McNollgast argues that these statements should be given no weight. $^{\text {past }}$

By contrast, some statements are credible, or at least more credible, because the speaker would incur a cost if he said something else. For example, if a committee report interprets compromise language in an extreme fashion, then the majority will vote down the bill. If the committee prefers the compromise language to no bill at all (the status quo), it would do better to report the accurate interpretation than the extreme interpretation. ${ }^{142}$ Therefore, the committee report's statement is (usually) credible. ${ }^{143}$ Similarly, language in an amendment that is voted down by the majority on the floor provides a clue, by way of negative inference, of the meaning of the bill. Here the majority's vote is the credible statement; if the majority voted in favor of the amendment, it would be worse off on the assumption that it prefers the unamended version of the bill. ${ }^{144}$

In sum, when using legislative history, courts should focus (1) on the statements of members of the enacting coalition, (2) when those statements are credible because the member has an incentive to speak truthfully or at least partially truthfully.

\section{B. SIGNING STATEMENTS}

How do these considerations bear on presidential signing statements? Initially, to keep the discussion simple, we will limit our focis to signing statements that provide an interpretation of the statute based on nonconstitutional considerations. Further, we will assume that a court will give weight to the signing statement in future litigation. We will relax these assumptions in Section $\mathrm{C}$.

The first criterion is that the president be part of the enacting coalition. As McNollgast acknowledges, the president will almost always be a member of the enacting coalition because he has the veto. Because Congress must craft the bill in such a way as to avoid the veto, the bill will almost always reflect the president's preference-except when the veto is overridden, in which case no signing statement will be issued. ${ }^{145}$ To be sure, there are

141. McNollgast, Positive Canons, supra note 138, at 737.

142. Id. at 722-24.

143. McNollgast, Legislative Intent, supra note 138, at 27-28.

144. Id. at 26 .

145. For an exhaustive analysis and empirical evidence, see CHARLES M. CAMERON, Veto Bargaining: Presidents and the Politics of Negative Power (2000); see also GeORge Tsebelis, Veto Players: How POLITICAl INSTITUTIONS WORK (2002); 
some circumstances where technically the president's preference does not affect the content of the bill. For example, if the president seeks a moderate bill that slightly changes the status quo, the relevant players in Congress seek a more extreme bill, but the president also prefers the extreme bill to the status quo, then Congress's preferences will determine the content of the bill; the president's is irrelevant. ${ }^{146}$ But as McNollgast acknowledges, these sorts of situations are more hypothetical than real; the president's influence is pervasive. The veto power is significant; also the president can sometimes set the agenda by proposing legislation and using his political and institutional resources (including his leadership of one of the political parties in Congress) to focus Congress's attention on his proposal. Therefore, it seems appropriate to assume that the president is always a member of the enacting coalition except when his veto is overridden.

The second criterion is that the president's signing statement be credible. McNollgast argues that it will not be credible because it occurs after Congress has voted. Congress does not have the opportunity to reject the president's statement; therefore, the president will state his preferred interpretation rather than the actual compromise interpretation. ${ }^{147}$ One might argue that the president's signing statement is in this way no different from the statements made by individual members of Congress who do not hold committee or other leadership positions, or indeed from the statements made by members of Congress after the bill has been passed and signed. ${ }^{148}$

To understand this argument, consider the following example. Suppose a liberal president supports a bill that prohibits certain emissions of a certain quantity but would strongly prefer a bill that bans these emissions altogether. The bill is ambiguous in

Steven A. Matthews, Veto Threats: Rhetoric in a Bargaining Game, 104 Q. J. EcoN. 347 (1989).

146. McNollgast, Positive Canons, supra note 138, at 722-23.

147. McNollgast, Legislative Intent, supra note 138, at 28; McNollgast, Positive Canons, supra note 138, at 726-27; McNollgast, Commentary, The Theory of Interpretive Canon and Legislative Behavior, 12 INT'L REV. L. \& ECON. 235, 237 (1992) (repeating this conclusion but also seeming to qualify it); see also Daniel B. Rodriguez \& Barry $\mathrm{R}$. Weingast, The Positive Political Theory of Legislative History: New Perspectives on the 1964 Civil Rights Act and Its Interpretation, 151 U. PA. L. REV. 1417, 1446 \& n.91 (2003); Daniel B. Rodriguez, Statutory Interpretation and Political Advantage, 12 INT'L REV. L. \& ECON. 217, 227-28 (1992) (expressing skepticism about the value of signing statements).

148. However, this type of material is sometimes used by courts. See ESKRIDGE, FRICKEY \& GARRETT, supra note 135 , at 1018 
part because of different views within the enacting coalition, most of whose members prefer the more conservative version of the bill and would not vote in favor of the liberal interpretation. Thus, the "intention" of the enacting coalition is the conservative interpretation - the emissions are limited, not eliminated. The president stays quiet during legislative deliberations while members of Congress advance the conservative interpretation of the bill. The bill passes with a bare majority in each house. In the signing statement, the president for the first time advances the liberal version of the bill. If he expressed this view prior to the final vote, and courts would accept this view, the bill would not have received a majority because a majority would not vote for a bill that would be given the president's interpretation by courts in subsequent litigation.

Thus, if courts gave weight to the president's signing statement, it would thwart the will of the enacting coalition. One view is that this is the wrong outcome in itself; but even if one does not hold this view, one must recognize that judicial deference to the signing statement would create all kinds of difficulties. Next time around, Congress knows in advance that the president will say one thing (or nothing) prior to the vote and something else after the vote. As a result, Congress may vote down bills whose compromise meaning it supports. Another possible consequence is that members of Congress will need to extract a commitment from the president not to advance a new interpretation in the signing statement. Even if the president can make a credible commitment, the additional bargaining costs are a deadweight loss. A third possible consequence is that Congress will need to expend additional time and energy crafting a bill that is detailed enough to foreclose an interpretation the president would be likely to advance in a signing statement. In these ways, giving weight to the signing statement interferes with desirable legislation without having an offsetting benefit.

This is the argument of McNollgast and other authors. We think it suffers from several difficulties.

First, the president's statements in general are more credible than those of members of Congress because the president is a more significant and visible figure, and he is more of a repeat player; thus, he has more to lose if he loses credibility. A president whose signing statement violates legislative bargains will have more trouble obtaining Congress's cooperation later on. $\mathrm{He}$ also might earn the distrust of other political actors and voters. In other contexts McNollgast seems to agree that general 
considerations of reputation encourage political actors to be honest. They point out that committee chairs have an incentive to be honest because they fear retaliation by the congressional leadership which can deprive them of their positions. ${ }^{149}$ But if this is true for committee chairs, it is also true for the president. Congress, members of his party, interest groups, and other parties with something at stake in the legislative process will refuse to cooperate with him in the legislative process if he reneges on earlier deals by issuing inconsistent signing statements.

Second, the president's signing statement is not like the statement of a member of Congress who is outside the enacting coalition or who has no incentive to speak sincerely because the vote is past. The distinction is that the president will usually have a significant role in the administration and enforcement of the statute, whereas the member of Congress does not. ${ }^{150}$ This is true for an ordinary criminal statute that is enforced by U.S. Attorneys or the Justice Department; regulatory statutes that are enforced by administrative agencies such as the EPA; and even laws creating private rights of action, at least to the extent that these laws overlap with other statutes that the president enforces or have some relationship to the president's constitutional powers such as his authority over foreign relations.

Thus, the statute in question may delegate authority to the president, and even when it does not do so formally it will usually quasi-delegate, in the sense of implicitly permitting the president to use discretion in enforcing the statute. Political scientists generally support delegation from Congress to the president, citing the advantages for Congress to leaving difficult policy questions to expert agencies that build up institutional capacity in particular areas of policy. ${ }^{151}$ In doing so, Congress takes the risk that the president will direct agencies to enforce laws in a manner that deviates from Congress's intent, but Congress can reduce this risk in two ways. First, it can use the Senate's advice-and-consent power, as well as Congress's general authority over personnel decisions, to ensure that the agency's

149. McNollgast, Legislative Intent, supra note 138 , at 26 ; see also William $\mathrm{N}$ Eskridge, Jr. \& John Ferejohn, Politics, Interpretation, and the Rule of Law, 36 NOMOS 265 (1994).

150. See Cross, supra note 1 , at 218 . However, Cross is more skeptical than we are because he fears opportunism on the part of the president. Id. at 224 . We address this concern below.

151. See, e.g., David Epstein \& Sharyn O'Halloran, Delegating Powers: A TRANSACTION COST POLITICS APPROACH TO POLICy Making UNDER SEPARATE POWERS (1999) 
preferences do not diverge too far from Congress's. Second, it can monitor the agency's behavior and use the diverse tools at its disposal-control over appropriations, oversight hearings, refusal to cooperate with the executive in subsequent legislative initiatives, providing for judicial review, ${ }^{152}$ impeachment, and so forth - to punish agencies that interpret laws in a manner that diverges too far from Congress's intention. Congress does not exercise perfect control over agencies, but the enormous advantages in institutional division of labor outweigh the costs.

For similar reasons, conventional wisdom approves of quasidelegations of power to the executive whenever statutes that require executive enforcement are enacted. Prosecutorial discretion in the enforcement of criminal statutes is just one of many manifestations of this view. ${ }^{153}$ When prosecutorial discretion is abused, Congress can use its oversight tools to retaliate against the executive. So the possibility of exercising that discretion in advance, in the form of a signing statement, should not raise any concerns. Rather than classifying signing statements as insincere forms of legislative history, one can more usefully think of them as policy statements by the executive that are constrained in the same way that all other exercises of delegated authority are.

Third, as noted above, PPT's main assumption - that legislative cost reduction is the goal of canons of statutory interpretation-ignores serious controversies about the legislative process. An alternative view is that the president more accurately represents the preferences or interests of the public as a whole than Congress does, because only the president has a national constituency. ${ }^{154}$ If we reject PPT's extreme pro-Congress assumption, then it is simply ambiguous whether the additional bargaining power that the president receives in a world in which courts give weight to signing statements enhances or reduces public welfare.

152. If Congress is worried that a president will misinterpret or decline to enforce/comply with a statute (whether through a signing statement or not), it can (within the broad bounds of Article III standing) provide for judicial review. Importantly, it did not do so in the Detainee Treatment Act - indeed, it did the opposite. Senator Specter recently introduced legislation that would purport to give Congress standing to seek judicial review of claims made in presidential signing statements and direct courts to ignore signing statements when interpreting legislation. See Presidential Signing Statements Act of 2006 , S. 3731, 109th Cong. (2006)

153. See, e.g., Lupton, supra note 121

154. For a recent summary of the vast literature that takes this view, with pertinent citations, see Jide Nzelibe, The Fable of The Nationalist President and the Parochial Congress, 53 UCLA L. REV. 1217, 1226-31 (2006). Nzelibe himself rejects this view. 
Although the danger of post-enactment opportunism by the president is real, this is something that can be constrained by courts. Courts can decide to give more or less weight to the president's views relative to Congress's when deciding how to interpret a statute. Courts that believe that the president has better incentives than Congress might give more weight to the signing statement than to ordinary legislative history, but that does not mean that the court would accept any kind of signing statement. Taking a cue from Chevron, ${ }^{155}$ a court might give weight to a signing statement that provides a reasonable interpretation of an ambiguous statute. Courts can also evaluate the credibility of the interpretive signing statements based on a variety of factors including consistency with prior signing statements and with statements by the president and other executive officials in the legislative history, the consistency of signing statements with the statements of members of Congress in the legislative history, the extent to which the statements generate disagreement from members of Congress, and so forth.

We can join the second and third points under the general claim that in the post-Chevron world signing statements are no more objectionable than exercises of presidential power that are now seen as routine and uncontroversial. Chevron dealt with formal delegations of power from Congress to the executive branch; but its rationales for judicial deference to executive interpretations of ambiguous statutes in such cases can be extended to signing statements. The two rationales for Chevron deference were the superior accountability and expertise of the executive. ${ }^{156}$ Our first point was about expertise: the president's enforcement authority gives him expertise about how statutes should be implemented. Our second point was about accountability: the president is more accountable to the public than courts are, and thus more likely to act in the public's interest. In Chevron, the Supreme Court used these rationales to justify deference to the interpretations of agencies that have formal rulemaking or adjudicatory power. Similarly, the president's expertise and accountability provide courts with a reason to give weight to signing statements rather than relying on their (the courts') own ability to resolve ambiguous language. ${ }^{157}$

155. Chevron U.S.A. Inc. v. Natural Resources Defense Council, Inc., 467 U.S. 837 (1984)

156. See id. at 865-66.

157. For a similar argument, see Cross, supra note 1, at 229-31. Political scientists generally support congressional delegation of authority to agencies for Chevron-style 
As we have noted, this reasoning has, in fact, been used by courts to justify deference to executive interpretations of statutes in various settings outside the Chevron setting. For example, courts give weight to executive interpretation of statutes that affect foreign relations. ${ }^{158}$ Similarly, they give weight to executive interpretations of treaties. ${ }^{159}$ When an agency does not have the power to issue formal rules that interpret the statute, the interpretation must be contained in other documents-memoranda, proclamations, executive orders, internal guidance statements, and so forth. If it is more convenient to advance these interpretations in signing statements, there is no reason to object to this practice. Indeed, in some contexts it may be preferable to have the president commit to an interpretation before specific controversies over the meaning of the law arise. In doing so, the President enhances transparency about his legal views and enforcement agenda. This proposition is also reflected in the disallowance of Chevron deference to executive litigating positions, which seems to be based on the concern that litigating positions might not reflect the considered view of the executive, or might be advanced for narrow political reasons. Because signing statements generally are made in advance of any particular dispute, ${ }_{160}$ and reflect the views of the president himself, it is less likely that they are similarly tainted. ${ }^{16}$

reasons. See, e.g., EPSTEIN \& O'HALLORAN, supra note 151. For a general discussion, see Eric A. Posner \& Adrian Vermeule, Interring the Nondelegation Doctrine, 69 U. CH1. L. REV. 1721 (2002). For an important exception, see William N. Eskridge, Jr. \& John Ferejohn, Making the Deal Stick: Enforcing the Original Constitutional Structure of Lawmaking in the Modern Regulatory State, 8 J.L. ECON. \& ORG. 165 (1992), who argue that Chevron upset the constitutional balance between the executive and Congress by enabling the executive to advance interpretations of statutes contrary to the enacting coalition's intention. In our view, Eskridge \& Ferejohn give too little weight to Congress's other means of control; do not adequately consider the possibility that economic and technological changes justify a shift in power; and also cannot account for the fact that Congress has continued to delegate substantial, discretionary authority to the president post-Chevron. See also Kagan, supra note 14 (endorsing broad administrative powers for the president on Chevron-like grounds).

158. See Curtis A. Bradley, Chevron Deference and Foreign Affairs, 86 VA. L. REV 649 (2000); Eric A. Posner \& Cass R. Sunstein, Chevronizing Foreign Relations Law, 116 YALE L.J. (forthcoming 2007).

159. See, e.g., Sanchez-Llamas v. Oregon, 126 S. Ct. 2669, 2685 (2006).

160. The signing statement issued in connection with the Detainee Treatment Act, however, occurred while litigation was pending challenging the administration's detention policies in the war on terrorism. As noted above, the Supreme Court in Hamdan disregarded the statement.

161. We are not claiming that signing statements are entitled to deference under the Chevron doctrine per se. Among other things, the applicability of that doctrine to presidential interpretations, as opposed to agency interpretations, is unsettled. See Acree v. Republic of Iraq, 370 F.3d 41, 63 n.2 (D.C. Cir. 2004) (Roberts, J., concurring). More. 


\section{COMPLICATIONS}

So far we have discussed interpretive signing statements. In this section, we expand our analysis by considering three additional issues. First, we address constitutional signing statements. Second, we relax our assumption that courts give weight to signing statements, and address the view that even if courts do not give weight to signing statements, it is still wrong for presidents to issue them. Third, we consider the differences between signing statements and other types of executive documents such as executive orders.

\section{Constitutional Signing Statements}

Many critics of signing statements have focused their attention on constitutional signing statements, statements that declare that the president will interpret the statute in a certain way, or not enforce certain provisions in the statute, because to do otherwise would violate the constitution. Critics fear that presidents use constitutional signing statements in order to rationalize executive aggrandizement at the expense of Congress and other institutions. Consider President Bush's statement that he will interpret a bill that bans certain cruel, inhuman, or degrading treatment of detainees in a way that does not interfere with his commander-in-chief authority, implying that Congress cannot prevent the president from ordering subordinates to engage in such treatment during wartime. ${ }^{162}$ Critics who believe that no reasonable interpretation of this statute would violate the president's commander-in-chief authority assume that the president is implicitly proposing more expansive powers than he already has. And even when there is a potential conflict between the statute

over, in United States v. Mead Corp., 533 U.S. 218 (2001), the Supreme Court held that Chevron deference is appropriate only when it is "apparent ... that Congress would expect the agency to be able to speak with the force of law when it addresses ambiguity in the statute or fills a space in the enacted law," id. at 229 , and it is not clear when this expectation applies with respect to the president. Rather, our claim is simply that the rationales for deference under Chevron provide support for giving at least some weight to signing statements, assuming that weight is given to other types of legislative history. Even when Chevron does not apply, lesser types of deference may be appropriate, such as "Skidmore deference," whereby the weight to be given to an interpretation "will depend upon the thoroughness evident in its consideration, the validity of its reasoning, its consistency with earlier and later pronouncements, and all those factors which give it power to persuade." Mead Corp., 533 U.S. at 228 (quoting Skidmore v. Swift \& Co., 323 U.S. $134,140(1944))$.

162. Statement on Signing the Department of Defense. Emergency Supplemental Appropriations to Address Hurricanes in the Gulf of Mexico, and Pandemic Influenza Act. 2)(16, 41 WEEKLY COMP. PRES. DOC. 1918 (Dec. 30. 21)(15). 
and the president's constitutional powers, one might fear that the president will use the statement to rationalize a refusal to enforce that statute even when no such conflict exists.

As we noted in Part III, a standard response to the critique of constitutional signing statements is that the president has a duty to comply with the Constitution - a duty that can be tied to the Take Care Clause, if need be. Thus, if the president believes that a statute violates the constitution, he has a constitutional obligation not to enforce it ${ }^{163}$ (As discussed above, the president may have a duty not to enforce an unconstitutional provision even if he does not have a duty to veto the provision.) Announcing his view on this matter in advance, in a signing statement, is surely preferable to waiting until litigation arises. By stating his view in advance, the president gives Congress an opportunity to correct the statute, and also helps align citizens' expectations with the law as enforced.

A critic might respond that the president should not exercise independent judgment about the constitutionality of the statute. Congress's implicit determination that the statute is constitutional is entitled to deference; or perhaps the president should suspend judgment until a court has ruled. These are all possible views, but they are hardly uncontroversial. Whatever the truth, our point here is narrow, and should by now be familiar. The criticism is not of the signing statement but of the content of particular signing statements. If one believes that the president has the authority to refuse to enforce statutes that he deems to be unconstitutional, then the only possible objection to a signing statement that says as much is that it comes too soon. But we see no reason why the president should defer announcing his view until litigation occurs. If one believes that the president does not have the authority to refuse to enforce statutes that he deems to be unconstitutional, that by itself is not sufficient for criticizing the statement of his views in a signing statement. To hold that position, one would have to believe that the president would have to keep silent regarding his constitutional views about a statute, a position held by no one of whom we are aware. If the president has the right to state his views about the constitutionality of a statute, then he should state his views sooner rather than later, in which case the signing statement would be the appropriate vehicle. And if the president's views about constitutional power are excessive, a court is free to disregard them.

163. See supra note 93 and accompanying text. 
The critic might also respond that the president should veto bills that contain provisions that he believes to be unconstitutional rather than sign them and issue a signing statement announcing his intention not to enforce the offending provision. By vetoing such bills, the president would discourage Congress from enacting unconstitutional legislation in the first place. But nothing is gained though such a course of action, and much is lost. Whether the president vetoes the bill or signs it but refuses to enforce unconstitutional provisions, the unconstitutional provisions have no legal effect. Vetoing, then, just creates costsdelay of enactment of the constitutional provisions or indeed failure of enactment altogether.

The basic fear seems to be that the president will use the signing statement in an opportunistic fashion to advance impermissible theories of executive power, and that these theories might stick even if courts do not pass on them or even if they reject them. How might such theories stick? We address this question in the next section.

\section{Nonjusticiable Signing Statements and the Evolution} of Constitutional Norms

Even assuming courts do not pay attention to signing statements, or are capable of discounting those that make extreme claims about executive power, there seems to be a lingering concern that the signing statement provides the president with an excessively potent weapon in its continuing separation-of-powers battle with Congress. The concern, discussed in Part II, that the president could direct subordinates to disregard provisions of a statute can be recast as a fear that the president can too easily thwart the will of Congress. A related concern is that by persistently advancing claims about executive power against an often weak-willed and divided Congress, the president will eventually persuade Congress, courts, or others that he has powers that he really lacks or ought to lack. So even if courts do not give weight to signing statements, they cause harm to constitutional norms and the division of powers between governmental units.

This argument is vulnerable to two objections. First, no one fully understands how the president and Congress use their various institutional advantages to encroach on the power of the other. Both sides have formidable tools at their disposal. The president is the focus of the nation's attention; he delivers nationally viewed speeches; he controls the law enforcement activities of the executive branch; he can use executive orders and 
proclamations; he can use the veto against statutes that implicitly deny him powers he thinks he has. In taking these actions, the president can argue that his constitutional powers are, or should be, greater than they in fact are (or should be), and if he persuades his audience, then his constitutional powers may indeed advance. But Congress can interrogate executive officials in oversight hearings; it can cut budgets, jurisdictions, enforcement powers; it can require reports and audits; it can (though the Senate) vet nominees and refuse to confirm them; it can order investigations of the president and his subordinates; it can impeach the president. Congress frequently passes bills with constitutionally dubious provisions that increase Congress's power: consider its continued use of one-House and committee veto provisions despite the Chadha decision. Congress frequently passes multiple bills and omnibus appropriations bills that contain numerous, unrelated provisions. These bills put the president in a difficult position. As a practical matter, the president may need to sign these bills even if there are unconstitutional provisions. Yet it is not self-evident that his behavior is clearly objectionable if he refuses to subsequently enforce an unconstitutional provision. That this is a serious problem is recognized by many state constitutions, which require the legislature to pass single-subject bills and give the governor a line-item veto. ${ }^{164}$

Given that both sides already have numerous tools for advancing their constitutional understandings, and that one cannot say whether the one side or the other has superior tools, whatever this might mean, it is impossible to say whether the signing statement gives the president a significant advantage over Congress. It might give him no advantage, a small but reasonable advantage, or it might make up for numerous disadvantages.

Second, one's position on these issues must depend on the resolution of a prior, equally difficult issue, namely whether the president already has "too much" or "too little" power relative to Congress. ${ }^{165}$ Arthur Schlesinger, Jr., thought that the presidency was too powerful when he wrote his book, The Imperial

164. See ESKRIDGE, FRICKEY \& GARRETT, supra note 135, at 330-31, 335-36; Courtney Paige Odishaw, Note, Curbing Legislative Chaos: Executive Choice or Congressional Responsibility?, 74 IOWA L. REV. 227, $230 \& 241$ (1988).

165. For discussion of this baseline problem, see M. Elizabeth Magill, Beyond Powers and Branches in Separation of Powers Law, 150 U. PA. L. REV. 603 (2001). The literature on the constitutional conflict between the president and Congress is vast. See, e.g., LOUIS FISHER, CONSTITUTIONAL CONFLICTS BETWEEN CONGRESS AND THE PRESIDENT (4th ed. 1997); Walter F. Murphy, Who Shall Interpret? The Quest for the Ulimate Constitutional Interpreter, 48 REV. POL. 401 (1986). 
Presidency, in 1973. By the year 1998, he had come to believe that the president was no longer too powerful, but then he changed his mind when he wrote the preface to a second edition in $2004 .{ }^{166}$ Schlesinger did not, at any time, provide a theory that explains how much power the president should have, so his judgments were no more than impressions. As we have noted, the executive has gained power throughout American history, and particularly during the twentieth century. Domestically, the president has become the leader of the regulatory state since the New Deal. Internationally, the president has increasingly enjoyed freedom of action, at least since the Spanish-American War. One cannot criticize the use of presidential signing statements to aggrandize executive power without being able to establish that the president currently, under the right understanding of the Constitution and American political institutions, has the right amount of power or too much. Far too much controversy exists on this issue for the criticisms of signing statements to be persuasive along this dimension.

\section{Executive Orders, Executive Memoranda, and Proclamations}

One of our recurrent arguments is that signing statements are just one of many tools that the president has at his disposal for controlling the executive branch. Other tools include executive orders, memoranda, proclamations, agency rules, and internal guidelines. To the extent that these other instruments are near substitutes for signing statements, then even some kind of prohibition of or taboo on signing statements, if this were possible, would have no effect on the conduct of the president. ${ }^{167}$ However, we have not gone so far as to say that signing statements are identical to these other tools, and indeed they are not. Accordingly, signing statements may indeed have significance.

The most interesting difference between a signing statement and the other types of documents is that a signing statement attaches itself to a statute, and so (if given weight by courts as legislative history) may continue to have force after the termination

166. SCHLESINGER, supra note 32 , at ix-xxiv.

167. See also T.J. Halstead, CRS Report for Congress, Presidential Signing Statements: Constitutional and Institutional Implications, at CRS-26 (Sept. 20, 2006) "It does not seem likely that a reduction in the number of challenges raised in signing statements, whether caused by procedural limitations or political rebuke, will necessarily result in any change in a President's conception and assertion of executive authority."), available at hitp://www.fas.org/sgp/crs/natsec/RL33667.pdf. 
of the administration, even if future presidents disavow it. For comparison, consider the executive order. At the beginning of their administrations presidents typically review executive orders from prior administrations, and repeal or modify those that they do not agree with. No one doubts that presidents can do this. Signing statements are anchored to statutes; executive orders float free.

Now, a president could also use an executive order to disavow a prior president's signing statement, or to instruct subordinates to disregard claims made in that signing statement. However, it is imaginable that in future litigation a court could rely on the signing statement and disregard the disavowal. This could happen if courts regard the signing statement as a part of the legislative history rather than as an independent statement of executive policy. When interpreting statutes, a court will rely on legislative history to some extent, but it does not always pay attention to the interpretations of the current president. In this way a signing statement could be a more powerful way to affect interpretations of a statute than other executive instruments are-even more powerful than a formal agency rule under the Chevron doctrine, which permits new presidents to reject interpretations of earlier presidents.

We emphasize that this is a possible argument, and we do not know how courts will act. But if courts do accept this argument, we think that this would on balance be a good thing. The reason takes us back to the theory of statutory interpretation. As long as the president is a member of the enacting coalition, then his contemporaneous interpretation of the statute is entitled to respect. Just as courts rely on the enacting Congress's intention, not the intention of the Congress in session at the time of litigation, they should rely on the "enacting president's" intention, not the intention of the president in office at the time of litigation. Indeed, courts do routinely rely on statements issued by the executive branch regarding legislation under consideration. ${ }^{168}$

\section{CONCLUSION}

The critics confuse the medium and the message. The signing statement is a tool for expressing a president's view of a stat-

168. See Otto J. Hetzel et al., Legisl.ative Law and Process: Cases and MATERIALS 438 ( $2 \mathrm{~d}$ ed. 1993) (noting the use of testimony by executive branch administrators, their analyses of bills, and messages from the president and his subordinates that propose or comment on pending bills). 
ute. The fact that presidents may use signing statements to advance erroneous views about their constitutional powers or the meaning of a statute is not grounds for criticizing the tool, just as policy disagreement about the use of the veto would not be grounds for criticizing the president's veto power. Like all tools, the signing statement can be used for good or for ill. Confusion about this point is evident in the debate about whether Bush has challenged "too many" statutory provisions in signing statements, when the appropriate question is whether Bush's views about executive power are justified. ${ }^{169}$

If courts do not give weight to signing statements, then the objections to this tool are weak indeed. The signing statement is no more offensive than the memorandum, the executive order, and the proclamation, and no one seems to want to ban them. Whatever one's views of presidential power, the president has the right and perhaps even a constitutional obligation to state his opinion about the meaning of a statute and whether it violates the constitution. If it is more convenient to state this opinion in a signing statement than in some other type of document, that is hardly an objection. Indeed, stating his views about legislation at the earliest possible point increases transparency about the executive's intentions, which enables those who are affected by the statute to adjust their behavior accordingly, and those who disagree with the president to mobilize resources to litigate or obtain a legislative revision.

If courts do give weight to signing statements, then critics of the signing statement should more appropriately complain about judicial than about presidential practice. But to the extent that courts legitimately defer or give weight to the executive's position on some issue, and this is very common as we have discussed, then it seems that use of the signing statement should be encouraged rather than criticized. When the president expresses his view in advance rather than in litigation, there is less of a chance that the view is opportunistic or politically biased, as courts have recognized. The signing statement should thus be preferred to the litigation position. And occurring as it does at the earliest point at which the president can express his views about a completed statute (as opposed to bills earlier in the legislative process), the signing statement is an attractive vehicle for doing so.

169. See Walter Dellinger, Editorial, A Slip of the Pen, N.Y. TIMES, July 31, 2006, at A17. 
We have also argued that if courts are correct to examine legislative history, then a signing statement should be examined as well, even though it comes after the vote. The president has legislative power embodied in his veto, and thus his views about legislation are entitled to some weight. The PPT models show that because Congress legislates under the shadow of the veto, a bill will reflect the president's view, even if only implicitly. And because the president will almost always play a role in the enforcement of a statute, his views about it, as embodied in the signing statement, are no more suspect than other instructions to subordinates. Because he is a usually a pivotal member of the legislative coalition, because he is usually charged with enforcement in the statute, and because his enforcement of the statute is politically constrained, his statement will often provide useful information about the meaning of the statute. 